\title{
Anatolian linguistic influences in Early Greek (1500-800 BC)? Critical observations against sociolinguistic and areal background ${ }^{1}$
}

\begin{abstract}
The paper addresses the question of the presence of Anatolian influence in Early Greek (conventionally, about 1500-800 BC). The first part addresses methodological questions of language contact, such as mechanisms of linguistic interaction and the scale of borrowings. In the second part, eleven important cases of presumable Anatolian lexical borrowings in Greek are critically analyzed. The results of the analysis suggest that the Anatolian influence on the vocabulary of Early Greek was minimal (if any), which strongly speaks against the possibility of influences in morphology, phonetics or phraseology.
\end{abstract}

Keywords: Greek-Anatolian interaction, Early Greek language, Anatolian languages, Hittite language, Luwian language, Lydian language, Lycian language, Carian language

It would be fair to say that the existence of some cultural influence of Anatolia on Greek language and literature which may be dated as far back as the Late Bronze Age is at present taken practically for granted. The assessments of the extent and depth of this influence, as well as of its exact source (the Hittites, the Luwians or some other peoples of Western or Southern Anatolia), may vary considerably from scholar to scholar, but the very idea seems to have assumed by now in the eyes of many (if not all) the quality of an established fact, mirroring in a way a similar process of 'recognition' of more general 'Oriental' influences in the early Greek literature. This belief is rooted in the obvious fact of immediate geographic proximity of Anatolia and the Aegean, in the somewhat less obvious but still demonstrable fact of contacts between the Mycenaean Greeks and Anatolian peoples and, lastly, in a far more problematic and often subconscious - belief that Anatolia as a part of the Ancient Near East was culturally superior to the Aegean world in the Late Bronze Age, which should allegedly have automatically made the Greeks receptive to cultural impulses from this region. The underlying belief in the importance of the Anatolian factor for the Early Greek language and literature generated over the years an imposing (even if not all too dense) swarm of publications claiming to have found one or the other concrete instance of Anatolian or, to apply the term most fre-

${ }^{1}$ The current paper was submitted as a part of project 'The Trojan Catalogue (Hom. Il. 2.816-877) and the Peoples of Western Anatolia in the Late Bronze Age and Early Iron Age. A Study of the Homeric Text in the Light of Hittite Sources and Classical Geographical Tradition' (2015/19/P/HS3/04161), which has received funding from the European Union's Horizon 2020 research and innovation program under the Marie Skłodowska-Curie grant agreement No 665778 with the National Science Centre, Poland.

At the core of the paper lies the talk given at the conference 'Language Change in Epic Greek and other Oral Traditions' (Leiden, 27-29 October, 2016) and the initial variant of the paper profited from the discussions with Lucien van Beek (the editor of the proceedings volume) and from the critical comments of an anonymous peer reviewer, to whom I express my gratitude. My further thanks go to Craig Melchert and Ilya Yakubovich, both for helpful suggestions and for correction of linguistic infelicities. Needless to say, all responsibility for the text remains my own.

Journal of Language Relationship • Вопросы языкового родства • 16/2 (2018) • Pp. 93-118 • C The authors, 2018 
quently used for the most part of the $20^{\text {th }}$ century, Hittite influence in the domain of Greek vocabulary, morphology or phraseology ${ }^{2}$.

The fact of geographic proximity of the Aegean and Anatolia and the existence of some sort of contact between the Greeks and the Anatolians in the Late Bronze Age is difficult to deny. However, these two factors still do not constitute a sufficient condition for existence of a cultural, linguistic or, even less so, literary influence of Anatolia on Greece. The very possibility and the direction of influence is determined by a far more complex and subtle combination of sociolinguistic factors which involve type and intensity of contact between two communities - which may or may not result in the situation of bilingualism - and, no less crucially, language attitudes within respective communities (see below for details).

Due in part to the above mentioned preconceptions and in part to the almost complete absence of direct evidence, the sociolinguistic dimension of the process of the Greek-Anatolian interaction was until recently practically left out of consideration. Ilya Yakubovich (2010: 140157) was the first to look at the issue against a sociolinguistic background. However, his treatment is more of a critical overview of the relevant evidence rather than a linguistic analysis within the framework of methods that are current in modern sociolinguistic discourse. Some theoretical points of language contact were touched upon by Ivo Hajnal (2014: 107-110), who posed the question whether Early Greek and Anatolian might be described as a sort of Sprachbund, as was assumed in some earlier studies (e.g., Puhvel 1991a or Watkins 2000a), or if the nature of the language contact was more casual. In his analysis he drew upon considerations on contact-induced language changes presented in Thomason \& Kaufman (1988: 37f., 65f.) which result from studies on modern and much better documented languages. As far as the question is concerned, Hajnal argued - rather unsurprisingly - against a Sprachbund scenario, coming to the conclusion that Greek-Anatolian contacts were rather confined in their extent and went exclusively in the direction East > West (i.e. Anatolia > Greece), resulting in some lexical borrowings but no structural changes in Greek (such as borrowing of morphological elements or changes in syntax). In a more recent treatment (2018), which largely repeats the argumentation of Hajnal 2014, a similar conclusion is reached. And yet, even while basically refuting the existence of bilingual communities on the Greek-Anatolian interface and accepting only a very limited number of Anatolian borrowings in Greek, Hajnal still quite optimistically assesses the existence of phraseological borrowings from Anatolia attested in the Iliad and other Early Greek literary works, ascribing them to an interaction on the level of 'literary subjects and genres'. The idea that it is possible to speak about an interaction on literary level which leaves no perceptible traces in the lexicon of a language - neither in the domain of common words, nor even in the domain of onomastics which is arguably quite easily transferred from culture to culture - raises serious doubts and would require a detailed discussion. The aim of the present contribution is, however, to re-address in greater detail the sociolinguistic and areal aspects of the problem which Yakubovich and Hajnal touch upon only tangentially. ${ }^{3}$

2 The popularity of the idea of Greek-Anatolian language contact is primarily due to the works of Jaan Puhvel and Calvert Watkins (see first of all Puhvel 1991 and the articles collected in Puhvel 2002, as well as Watkins 1995, 1998, 2000a, 2000b, 2007). For further literature and for a general good overview of the recent state of research in the field see Bianconi 2015. The recent monograph by Mary Bachvarova (2016), although building in part on linguistic argumentation, rather represents an elaboration of the topic from a literary/cultural perspective. The idea of more general 'Oriental' influences in Greek literature, inspired primarily by the works of Martin West (1997) and Walter Burkert (1992, 2004), recently saw a significant surge of interest (cf., e.g., López-Ruiz 2010, Haubold 2013, Metcalf 2015).

3 The question of sociolinguistic mechanisms of borrowings and 'migration' of terms in a certain area (Wanderwörter) was also recently discussed in two largely identical articles by Pozza-Gasbarra (2014a and 2014b). How- 
The first part of the paper will address the basic premises of the question about how and why a linguistic feature can be adopted from a foreign linguistic/cultural milieu, in other words, the sociolinguistic mechanisms of borrowing, with which the question of the scale (or hierarchy) of borrowings is further connected. In the second part I will give a critical revision the most important cases of supposed Anatolian lexical influence on Greek. Needless to say, the aim of this revision is not to give a full re-assessment of the situation - a task which would require a special monograph - but first of all to demonstrate the problems and caveats associated with the idea of Anatolian linguistic influence on Greek.

\section{An analytical framework: mechanisms of linguistic interaction and the scale of borrowings}

1) Quite naturally, theoretical issues concerning language interaction and mutual influence are rarely touched upon in discussions of dead languages attested through relatively small text corpora. Linguistic influences are here either quite obviously suggested by the material itself, as is, for instance, the case with the influence of the Prakrits on Tocharian or Greek on Coptic, or follow from more general historical considerations, as is the case with the influence of the Aegean substratum language(s) on Greek and comparable substratum scenarios, even if an exact quantitative assessment remains rather difficult in such cases. However, theoretical issues become crucial when one has to deal with interaction of two (or more) contemporary languages in neighboring regions (adstratum scenarios), when neither the direction nor the very existence of an influence is quite obvious. Geographic proximity and some contact between two communities, putative or actually documented, do not guarantee alone any linguistic or literary influence of one culture on the other. One can find numerous examples across the word when geographic proximity and contact between two linguistic communities result in no or practically no influence of one language on the other (let alone the literary level). An obvious example from the European linguistic area would be an extremely meager number of Celtic loanwords in standard British English, despite hundreds of years of close coexistence and significant intermixture of the two linguistic communities. The case is all the more remarkable given that the culture of different Celtic peoples, such as the Welsh or the Irish, at the end of $1^{\text {st }}$ and beginning of $2^{\text {nd }}$ can be in no way characterized (by modern scholars) as inferior to that of the Anglo-Saxons or the Normans. On the other hand, the heavy layers of Latin, French and Scandinavian borrowings in English show that the language was not just 'open' or 'closed', in a binary manner, to external influences - it was selective about the source. In other words, sociolinguistic factors play an extremely important and, in many cases, crucial role.

Further examples, also strongly tied to the question of language attitude, would be the more than modest number of Slavicisms in German or of words of indigenous origin in the American variety of English; in both cases the borrowings are restricted to very specific - virtually terminological - spheres, such as plant and animal names, cuisine, names of specific household items, cultural practices etc. and have almost no exponents in the everyday lexicon. Thus, without at least a rough assessment of sociolinguistic factors and language attitudes it is impossible to make any a priori claims about linguistic or literary influences of one culture on another, and the case of Greek and Anatolian is no exception. A preliminary assessment of so-

ever, the perspective adopted by the authors appears to be too general to be useful for the present inquiry. Unfortunately, I was unable to gain access to an earlier contribution of the authors to the question of Greek-Anatolian interference (Gasbarra-Pozza 2012). 
ciolinguistic factors in Aikhenvald-Dixon 2001: 14-16 recognizes seven relevant parameters which apply to both sides of interaction:

a) Type of community, which refers both to its internal organization ('tightly-knit' vs. 'loosely-knit') and the degree of openness to interaction with neighbors. The lifestyle of a given community (e.g., nomadic communities of different types, village agriculturalists, urbanized societies etc.), social organization and even marriage patterns (which affect transmission of language between generations) may play an important part in it.

b) Size of the community.

c) Relations within a community, i.e. first of all hierarchical structure of a given society and relations between different strata.

d) Type of contact with other communities, which involves both frequency of contact (regular vs. sporadic), circumstances (trade, religious/cultic interaction etc.) and, again, social level on which the contact takes place.

e) Degrees of 'lingualism', which describes the mode of usage of two or more languages within a given community. It is crucial whether a certain multiethnic community may be described as bilingual or multilingual - or the nature of contact does not presuppose any degree of 'lingualism' at all.

f) Type of language interaction: one-to-one interaction between two languages or interaction between one language and a group of closely-related languages.

g) Language attitude, which describes more or less conscious strategies of dealing with foreign elements. This may range from unrestricted and unconditional acceptance of borrowings to creative adoption of external influences using internal capacities of one's own language ('loan translation') to a complete ban on or ignorance of foreign elements.

Needless to say, far from all of these factors can be assessed with any accuracy for the case of Greek-Anatolian interaction in the Late Bronze and Early Iron Age (before ca. 800 BC). Still, some clues do exist and the situation they seem to imply is, to say the least, far from telling about any Anatolian influence on Greek. To begin with, judging from archaeological evidence, which is practically the only available source for the given period, the Greek-Anatolian contact zone was rather 'slim' in the Late Bronze Age, being effectively confined to the coastal zone of western (mainly its central part corresponding to Ionia) and possibly South Western Anatolia (Lycia). ${ }^{4}$ Furthermore, it was not continuous, but concentrated in several pockets corresponding to major urban centers; with some probability one may speak about more or less continuous presence of some Mycenaean Greek communities only in Miletus/Milawanda, in the region of the lower Hermos (the archaeological site of Panaztepe) and, somewhat more speculatively, in Ephesos/Abasa and a couple of other cities. ${ }^{5}$ In the Early Iron Age the territory of Greek settlement in western Anatolia expanded in quantitative terms, but the pattern remained essentially the same: urban centers in the narrow coastal zone which were open towards the sea with its trade routes but had rather little interest for the Anatolian hinterland beyond their respective city state territories (choras). There are hardly any reasons to assume that the mode of colonization of the West Anatolian coast was any different from colonization patterns ob-

${ }^{4}$ For a general picture of the distribution of Mycenaean pottery see Mee 1978 and especially Mountjoy 1998 with maps on pp. 38 and 52.

${ }^{5}$ It is quite probable that the Greek-speaking communities were also present in the Late Bronze Age Troy (Wilusa). However, there are strong doubts that Troy, as well as the whole north-western part of Anatolia (the Troad and Mysia), can be properly defined as 'Anatolian' in an ethnolinguistic sense (i.e. speaking one of the languages belonging to the Anatolian branch of the Indo-European languages). This question, which is the subject of the ongoing project of the author, will be addressed in detail elsewhere (cf., however, some considerations in Oreshko 2017). 
served for instance in Southern Italy or on the northern Black Sea coast or in Egypt (Naukratis), where the defining feature was creation of Greek enclaves in the foreign ethnolinguistic milieu with only very limited (if any) attempt of integration of (or into) the pre-existing communities.

The Greek settlement in Pamphylia and Cilicia went quite possibly along somewhat different lines with a somewhat higher level of interaction with and integration into the local communities (as was also the case with Cyprus). However, there are no evidence that the Greek communities there functioned as 'channels' of Anatolian influences into Greek in general (i.e. core literary dialects as Attic-Ionic and Doric); if there was any Anatolian linguistic influence on Greek in Pamphylia, as the scarce evidence of the Pamphylian dialect seems to suggest, or Cilicia (where there is no evidence), it remained rather a local matter (cf. again the case of Cypriot dialect). ${ }^{6}$ The only site in the inland Anatolia for which we have direct evidence suggesting some Greek presence in the Archaic period was Sardis (Sappho and Alcaeus); it is, however, questionable if this situation may be projected to back before $800 \mathrm{BC}$.

The next factor about which one can make some reasonable guesses is the nature of contact with indigenous Anatolians in the Late Bronze Age. There is every reason to think that the driving force of Mycenaean presence in Anatolia was 'economical' considerations: trade and, probably even more so, piracy and raiding, as suggested by the evidence of archaeology and scarce textual sources (Hittite and Linear B) ${ }^{7}$. This circumstance predicts rather precisely the type of Mycenaean Greek communities active in the Late Bronze Age in Western Anatolia: tightly-knit groups of male warriors and traders, probably not too different from the groups of Vikings active in the medieval Europe and beyond. Contact with indigenous Anatolian communities was characterized at best by a cautious (material) interest, but may have frequently been rather strained. Contact in the sphere of religion and cult, although frequently conjectured $^{8}$, remains a rather speculative possibility.

In the Early Iron Age, the pattern must have changed: the Greek settlements founded in the course of Aeolian, Ionian and Dorian migrations on the west-Anatolian coast represented full-fledged communities which included women and groups of any age and social strata. Both the size of the Greek communities in Western Anatolia in the Early Iron Age and the sociolinguistic pattern of their coexistence and interaction with the local communities are extremely difficult to assess even approximately. However, if there is no reason to doubt contacts on the level of individuals and, accordingly, the existence of a number of Greek-Anatolian bilingual speakers ${ }^{9}$, virtual absence of any literary evidence about long-term co-existence and/or intensive and regular interaction between Greek and, first of all, West-Anatolian communities in a specific common space and non-military context shows, at the least, that it was not common practice (again, the only exception seems to be Sardis).

${ }^{6}$ For Pamphylian see, e.g., Filos in Giannakis 2014: s.v. with further literature. There is no evidence about Greek spoken in Cilicia, although the joint evidence of Greek sources and Luwian inscriptions from Cilicia (KARATEPE and ÇINEKÖY) implies that the Greeks did settle there; in all probability those Greek communities shifted to the local idiom (Luwian) soon after the settlement (cf. considerations in Yakubovich 2015).

7 The few mentions of the Mycenaean Greeks ('Ahhiyawa') in Hittite texts suggest quite tense relationships, if not open hostility (see Beckman et al. 2011 with an overview of the issue on pp. 1-6 and 267-283, cf. also de Fidio 2008: 99-102). The evidence of Linear B texts mentioning female captives ( $r a-w i-j a-j a)$ from the regions of the West Anatolian coast and the nearby islands (as ki-ni-di-ja 'Knidian women' or ki-si-wi-ja, possibly 'Chian women') indirectly supports this, also implying that slaves were possibly one of the main 'articles of commerce' of the Mycenaeans in Anatolia (for captive women cf. also Chadwick 1988: 91-92).

8 See, e.g., Rutherford 2008, Mouton-Rutherford 2015, Teffeteller 2015, cf. also Bachvarova 2016: 216-265 for religious festivals as milieus for inter-cultural encounters.

${ }^{9}$ For bilingual individuals see, e.g., the examples adduced in Hawkins 2010: 220-221. 
However, probably the most significant if not crucial part in shaping the relationship between Greek and Anatolian (as any other language of the Ancient Mediterranean and beyond) was the Greek attitude to the foreign peoples in general and their languages in particular. The available evidence, however incomplete it is, plainly warns against the idea that Early Greek was readily open to any linguistic influences going from outside. Indeed, a very remarkable feature of the Greek picture of social cosmos was a sharp contrast between 'Greek' and 'nonGreek' ('Barbarian'). It is quite probable that this attitude had crystallized only during the Persian wars at the beginning of the $5^{\text {th }}$ century BC. However, it could not emerge overnight as a reaction to this encounter and its roots should lie much further back in the past. ${ }^{10}$ An important criterion of the distinction 'Greek' vs. 'Barbarian' was, along with perceived ethic affinity, religion and the way of life, quite naturally, language. And, just as the pattern of the Greek settlement abroad in relatively closed communities correlates well with the Greek attitude to the 'Barbarians', the linguistic evidence, when seen from a broad areal and chronological perspective, shows that Greek was rather restrictive towards external linguistic influences or, at least, very selective. If one takes out of consideration the words which can with different grades of confidence be classified as coming from the Aegean substratum language(s), ${ }^{11}$ the number of borrowings in classical Greek before Hellenistic period from any of the contemporary languages of the neighboring peoples is quite modest.

In a nutshell, the picture may be sketched as follows: the influence of the languages of the Balkans, Illyrian and Thracian, is, as far as one can judge from the extremely limited knowledge of these languages, barely noticeable in Greek. Even if one adopts an optimistic approach and counts the words transmitted as glosses which have an appearance of usual borrowings

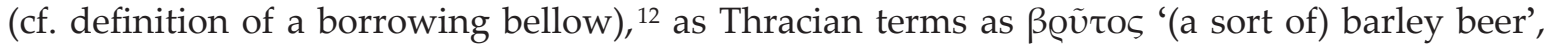

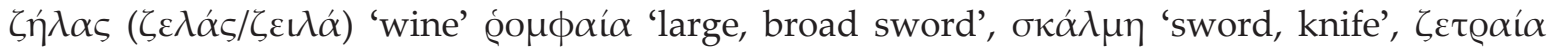
'(a sort of) pot', 13 one may speak at best only about some Thracian influence in peripheral Greek dialects. ${ }^{14}$ Likewise, there is hardly any reason to assume any significant influence of Phrygian on Greek. In this case even glosses, consisting in the most reliable cases practically

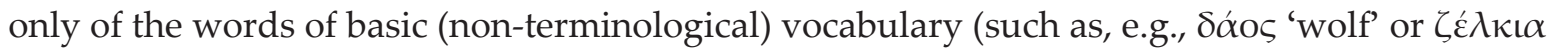
'garden-herbs, vegetables'), does not suggest any actual presence of Phrygian borrowings in Greek dialects. ${ }^{15}$ On the other hand, there is demonstrably Greek influence in Phrygian which

${ }^{10}$ On the Greek ethnocultural picture in general see, e.g., Cartledge 1993; for the reflection of this picture in the Histories of Herodotus, one of the most important sources in this respect, see Laurot 1993, cf. further Munson 2005. For more specific discussion see Coleman 1997, Tuplin 1999, Hall 2002: 90-124 (esp. 111-117 for the linguistic factor).

${ }^{11}$ For the substratum Aegean material in Greek s. most recently Beekes 2014, esp. Chapter 6 ('The Pre-Greek Lexicon'), cf. also an overview by Silvestri in Giannakis 2014: sub 'Pre-Greek Substrate'. However one assesses Beekes' analysis of individual cases, the fact is that the number of words in Greek which defy more or less plausible explanation from Indo-European is rather significant.

12 However, the words attested as glosses but found nowhere else, i.e. in theory known to Greeks but not in actual use, can be more correctly defined as foreign words (cf. below).

${ }^{13}$ Cf. Tzitzilis in Giannakis 2014: sub 'Greek and Illyrian' and 'Greek and Thracian' with further refs.

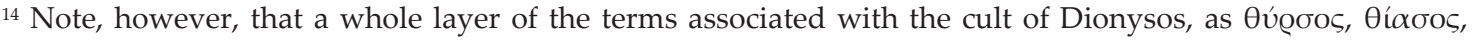

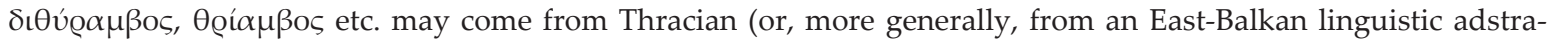
tum), as many features of the Dionysian cult have clear association with Thrace. In general, there are good chances that the Thracian (or East-Balkan) element in the Greek lexicon is underestimated due to poor knowledge to linguistic situation there. A significant amount of words dubbed as 'pre-Greek' may come from this region.

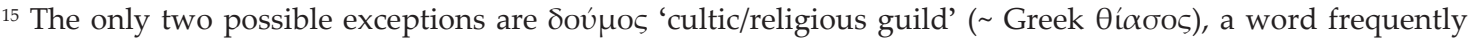
found in Greek inscriptions from Lydia and Phrygia, and $\gamma \alpha \dot{\alpha} \lambda \lambda \varsigma_{\text {o }}$ 'priest of the cult of Cybele', well attested in Greek and Latin authors. For the material cf. Haas 1966: 157-172 (with often far-fetched interpretations) and Sowa 2007 and Sowa 2008: 39-68. 
may possibly go back to a very early period, cf. lavag[e]ta- < $\lambda \alpha \mathrm{F} \alpha \gamma \eta \dot{\tau} \tau$ (Myc. ra-wa-ke-ta), vanakt- 'king' < (F)ä $\alpha \alpha \xi$ (Myc. wa-na-ka) attested in the Old-Phrygian period (M-01b) or later

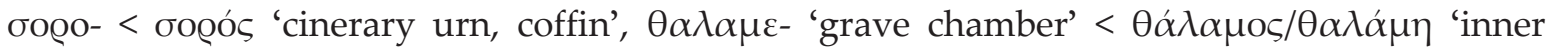
room, chamber; grave chamber', кo@o- < poss. $\chi \tilde{\omega} \varrho \varsigma^{\prime}$ 'piece of ground, land'. ${ }^{16}$ Again, quite a similar situation is found with the Anatolian languages attested in alphabetic transmission after ca. 700 BC, such as Carian, Lydian and Lycian. There are no demonstrable borrowings from either Carian or Lycian into the core Greek dialects and there is only very slight lexical influence of Lycian on the variety of Greek spoken in Lycia which reflects local realities and customs ( $\mu \iota \nu \delta\llcorner\varsigma / \mu \varepsilon v \delta ı \tau\rceil \varsigma$ 'a supervisory authority (of elders)' < Lyc. miñt(i)- and, more speculatively, $\pi \varepsilon \alpha \tau \varrho \alpha / \pi \iota \varepsilon \tau \varrho \alpha$ 'a term of relationship' (possibly, daughter-in-law)). ${ }^{17}$ This is, however, contrasted with clear evidence of Greek influence in Lycian, both lexical (e.g., stala- < $\sigma \tau \alpha \dot{\lambda} \alpha$

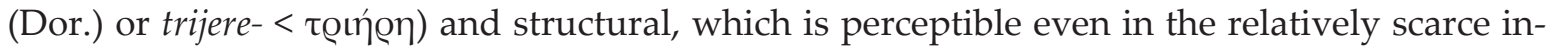
scriptional material we possess. For Carian, we have a testimony of Strabo (14.2.28) that it absorbed many Greek words in it. ${ }^{18}$ Only in the case of Lydian there are some reasons to assume a somewhat stronger influence. ${ }^{19}$ There are at least three good cases of Lydian words in Greek which may be termed as proper 'borrowings' or, at least, as 'well-known foreign words' ( $\pi \alpha \dot{\alpha} \lambda \mu v \varsigma, \kappa \alpha u ́ \eta \varsigma$ and $\beta \alpha ́ \kappa \kappa \alpha \varrho \iota \varsigma$, for which cf. below) and the Lydian material preserved as glosses makes an impression of somewhat more substantial knowledge of Lydian by Greeks than can be assumed for Lycian and Carian. ${ }^{20}$ This correlates well with the probable presence of a Greek community in Sardis noted above. However it might be, in Lydia as well as in Caria and Lycia the population finally completely shifted to Greek, which once again clearly demonstrates the sociolinguistic status of Greek as a prestige language of the region and the main direction of influence. Greek was arguably more susceptible to the influences going from the cultures of the Near East and the greatest number of borrowings can be attributed to two eastern language groups: Semitic (first of all west-Semitic) and Iranian (first of all Persian). The number of certain borrowings from each of these two groups comprises at least two dozens. ${ }^{21}$ However, these two cases make the statement about the selectiveness of Greek in absorbing foreign influences even clearer. As for Semitic influence, it is clear that it comes from an intensive cultural and trade interaction between coastal and maritime cultures of the Levant -

${ }^{16}$ Cf. Ligorio-Lubotsky 2013: 194.

17 See Melchert in Giannakis 2014: sub 'Greek and Lycian' with further refs. It is noteworthy that the few Carian 'glosses' all but one of which are preserved by Stephen of Byzantium, have rather dubious appearance (for the material cf. Adiego 2007: 455, cf. 7-12 with further refs.). At least in one case the explanation is clearly wrong: A $A \alpha \alpha \beta \alpha \nu \delta \alpha$ has nothing to do either with 'horses' (allegedly $\alpha \lambda \alpha$ ) or with 'victory' ( $\beta \alpha v \delta \alpha)$, but goes back in all probability to *ala-wanda- (with fortization $/ \mathrm{w} />/ \beta /(>/ \mathrm{b} /)$ ), which contains the usual toponymic suffix -wanda- with possessive function and is based on the noun ala/i- (attested in Luwian). Only the gloss by Eusthatius

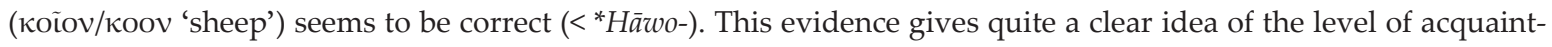
ance of the Greeks with Carian.

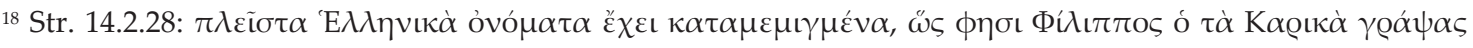
'It has many Greek words mixed in it up, as says Philippos who wrote Carica'. Phillipos which Stabo refers to is

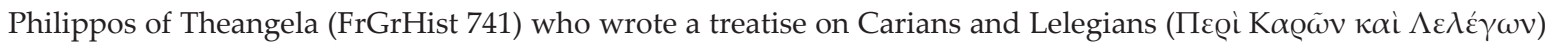
of which only four brief mentions are extant (fr. 5 preserved by Stephan of Byzantium which mentions a certain $\Theta \varepsilon \alpha \gamma \varepsilon \dot{v} \eta \varsigma$ in connection with a Cilician city K $\alpha \sigma \tau \alpha \lambda$ í $\alpha$ hardly belongs here). Given that Philippos was born in a Carian city, it is quite likely that he spoke or at least had some passive knowledge of Carian.

${ }^{19}$ However, there are reasons to asume that the case of Lydian is quite different in its essence.

${ }^{20}$ For a discussion of Lydian material see Hawkins 2013: 155-194, cf. Gusmani 1964: 271-278.

${ }^{21}$ For Semitic loan-words see Masson 1967 and Rosół 2013, cf. also an overview by Zaborski in Giannakis 2014: sub 'Semitic Loans in Greek'. For Iranian see Schmitt 1971, Brust 2005, cf. short overviews in Benvenuto in Giannakis 2014: sub ‘Greek and Iranian’ and Hawkins 2010: 226-227. 
'Phoenicians', comprising both the Phoenicians strictu sensu as well as the Syrian and Canaanite coastal peoples - and the Greeks, both in the Levant and in the Aegean and the wider Mediterranean, as is well documented by different sources. The presence of the Semitic borrowings perfectly correlates with the presence of the 'Oriental' influences in the material culture of the Aegean, especially strong around 800-550 BC. It is noteworthy that in the case of the earliest 'Oriental' words attested already in the Mycenaean Greek, such as sa-sa-ma 'sesame' or ku-mi-no 'cumin', it is more correct to speak about areal words (Wanderwörter), which were quite probably present in the Aegean substratum language(s) before the arrival of the Greeks, since nothing suggest that these words originated in one of the Semitic languages (for sesam cf. below). This applies to many of the alleged Anatolian 'borrowings' discussed below. Iranian or Persian influence in Greek dates after ca. 540 BC and clearly reflects significant political and cultural influence of the Persian Empire in the Eastern Mediterranean and Anatolia. Whether opposing or sympathizing the Persians (cf. $\mu \eta \delta\llcorner\sigma o$ ós), the Greeks could not remain absolutely immune to this influence. However, even in this case the absolute majority of the Persian words in Greek represents specific terms reflecting peculiar habits and realities of the

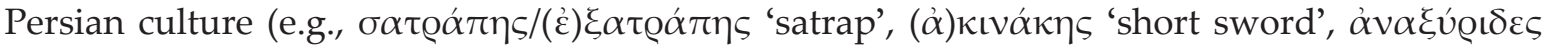
'trousers', $\mu \alpha \dot{\alpha} \varrho ı \varsigma$ 'a liquid measure' etc.) and represent well known foreign words rather than true borrowings fully embedded in the Greek language. It is noteworthy that in several cases we seem to deal with loan-translations of Persian titles rather than borrowings (cf. $\beta \alpha \sigma \lambda \varepsilon u ́ s$ $\beta \alpha \sigma \iota \lambda \dot{\varepsilon} \omega \nu$ 'king of the kings' or $\chi \iota \lambda \iota \alpha ́ \varrho \chi\rceil \varsigma$ 'commander of thousand').

Lastly, this picture may be complemented by literary evidence concerning foreign languages or, rather, almost complete absence thereof. The extant corpus of Greek texts conspicuously lacks both reasonably clear passages in foreign languages and any serious discussion of foreign linguistic material. ${ }^{22}$ The few possible exceptions, such as a supposedly Lydian expression preserved in Hipponax fr. 92 (= 95 Degani) or a Persian phrase in Aristophanes' Acharnians (100), corrupt as they are, only prove the rule. ${ }^{23}$ The Greek society, as reflected in literary texts, appears to be monolingual par excellence, even if in the Aegean were arguably present elements of many different ethnicities. There is an obvious and stark contrast with such multi-ethnic and multi-lingual societies as existed, for instance, in the Hittite Empire, where at least five different languages were in some currency in the capital besides Hittite itself (Akkadian, Hurrian, Luwian, Palaic and Hattian) or in the Achaemenid Empire with its documented usage of at least three different administrative languages (Aramaic, Akkadian and Elamite) and arguable currency of at least two other Iranian languages besides Old Persian (Median and Avestan).

In sum, there is fair amount of evidence that the Greek of the $1^{\text {st }}$ millennium BC was on the whole restrictive towards external linguistic influences. One should note that, besides purely political factors - which are not always a sufficient condition for acquiring by a lan-

22 The foreign languages, such as Lydian or Carian, might have been touched upon in special works concerning local histories, as, e.g., Lydiaka by Xanthos the Lydian (FrGrHist 765) or Carica by Philippos of Theangela (FrGrHist 741, cf. above fn. 18). This material might have served as the source of glosses preserved in the compilation by Hesychius. Even if this was the case - for which there is little tangible evidence - this would again be rather an exception which proves the rule: both mentioned authors were in all probability of a mixed ethnic background and their interest to the local history and culture is quite natural.

${ }^{23}$ For the Lydian expression in Hipponax' text, which probably served as basis for several glosses of Hesych transmitted in a number of significantly deviating variants, see discussion in Hawkins 2013: 157-166. For a discussion of the Persian phrase in Aristophanes see Willi 2004. Similarly, a brief and rather naive discussion of Phrygian words in Plato's Cratylus (410a) does not make an impression of a real interest to or knowledge of Phrygian (for a recent discussion against a linguistic background see Lamberterie 2013: 50-54). 
guage the status of a prestige idiom - this quality correlates with extreme richness of Greek in internal linguistic capacities, which allowed Greek to develop a number of literary and scientific registers highly prestigious and influential in the Mediterranean and beyond. Of course, one cannot simply project this picture back into Late Bronze Age. However, at least some of the prerequisites of the attitude to the foreign might well have been present already then and the situation of interaction between Greek and Anatolian communities at that time does not seem to be especially advantageous for formation of bilingual communities. Thus, even if there might have existed a number of exceptional cases, the overall picture of Greek-Anatolian contact does not imply any significant cultural or linguistic influences in either direction.

2) Now let us look how differences in intensity of language contact affect language change. The borrowing scale discussed in Thomason \& Kaufman (1988: 74-95, cf. Thomason 2001, 59-98, esp. 70-71) represent, despite its understandable restrictions as any abstraction, a quite precise analytical instrument, at least under the normal scenario of a language contact. ${ }^{24}$ The authors define four stages of contact intensity, but for the present purposes it would suffice to look at the first two. On the first stage, the most casual type of language contact with rather few bilingual speakers, one has borrowings exclusively in the lexical domain with no structural changes on any level. Moreover, one borrows only from non-basic vocabulary; in practice this means that one borrows first of all nouns (rarer verbs or adjectives) with specific or even technical meaning, i.e. terms that are simply absent in the receiving language, such as, for instance, names of some professions or titles, of specific objects or cultural practices, plant and animal names etc (cf. above for the possible Thracian or Persian borrowings). On the second, more intensive stage, when some proportion (still not the majority) of population is 'reasonably fluent bilinguals', some function words, such as conjunctions, can be borrowed, and some slight structural influence of one language on the other may be observed, such as sporadic usage of new syntactical structures or new phonemes in borrowed words (as contrasted with the adaption of borrowings to the phonetic system of one's own language on the previous stage). Re-interpreted in less abstract terms, this means that in the situation of a language contact one starts always with acquiring separate words (or, rarer, their combinations), which for one or another reason appear to be important. It is quite obvious that this corresponds to the very first stage of language acquisition by a child (or by a person going on a trip abroad). Correct syntax and phonetics are much less important things and can be for the time being ignored; only after becoming a more or less fluent bilingual speaker, one may turn attention to the subtleties of phonetics, syntax and idiomatic expressions of the second language, which may become with time so familiar that they begin to influence the first language. For the present purpose the most significant inference of this brief survey is the primary importance of lexicon as an indicator of language contact. In order to be able to demonstrate an influence of one language upon another one needs to present a more or less significant number of clear lexical borrowings. Before that, there is simply no point to look for similarities in morphology, syntactical structures or idiomatic expressions: they simply cannot come into being if one is not a fluent bilingual speaker, which should necessarily leave perceptible traces in the lexicon.

3) Lastly, it is appropriate to address briefly the question of what is a borrowing (loanword) and what is its difference from a Wanderwort to avoid misconceptions. Thus, cheetah is a borrowing in English from Hindi, because (a) cheetahs do not live on British Islands and, consequently, neither Celts nor Anglo-Normans needed a special word for the animal; (b) cheetahs do live in India with which the British arguably had close contact from the early 17th century on and where they quite probably first saw the animal; (c) Hindi as a specific source language

${ }^{24}$ Cf. also the hierarchy of lexical borrowing in Winford 2013: 176 (with further refs.). 
of borrowing - and not, for instance, a language of Iran, a land for which both the presence of cheetahs and, at some point, of the British subjects is documented - is indicated by joint evidence of the word's phonetics and semantics: in Hindi the word chìtā means 'variegated, spotted' (< Skr. chitra), which is quite an appropriate description of the cheetah's appearance (in contrast, in Farsi cheetah's usual name is yuz palang). It is noteworthy that in this case the choice between the definition of the word as a true borrowing or as a foreign word - a word not fully embedded into a language and used in restricted number of contexts virtually as a terminus technicus - is not quite obvious; however, the fact that the word is known to the majority of English speakers and that the phrase 'he rushed to his breakfast as a cheetah' would make sense without any reference to Near Eastern or African context (cheetah = swift animal) still speaks in favor of the former possibility. Similarly, the fact that the word pajamas is ultimately a borrowing from Persian is defined by the fact that a word almost phonetically identical to it (pāi-jāme) is known in Farsi as a name for loose trousers not typical for Europe, and has there a transparent internal form ('leg-garment'); one only needs to assume the relatively unproblematic semantic change 'loose trousers' > 'loose (sleeping) suit'. The only difficulty is that the word is also attested in the languages of India, so the question arises how one should properly define it: as an Iranian borrowing or still as an Indian one.

These two examples demonstrate the basic principles associated with linguistic borrowing: (a) one usually borrows first words for objects/notions absent in one's own language; (b) the borrowed word has a phonetic form that is very close to the one in the source language with only basic adjustments to the phonetic system of the receiving language; (c) it has identical or very close semantics in both source and target language; (d) the most reliable criterion for defining the ultimate source of borrowing is etymological transparence in a given language; a rough idea where the word might come from may, however, be obtained by looking for the region where certain plant, animal, object or custom likely come from. There are, of course, some exceptions, e.g., the word alcohol, which is a borrowing from Arabic al-kohl 'antimony' (black powder used to highlight eyelids) with a non-trivial and multi-stage semantic change > 'easily sublimated substance' > 'spirit' > 'ethanol' > 'hard liquor'; such cases are, however, extremely rare.

As for Wanderwort, i.e. migrant cultural word, its principal distinction from a borrowing is that its ultimate source language is impossible to pinpoint with any certainty. A frequent mistake is to ascribe to a Wanderwort a certain origin simply on the basis of the earliest or relatively more frequent attestation in a given language (or a language group); as a typical example, one may mention the recurrent claim that sesame is a Semitic word, while in reality the distribution of wild species of the plant suggests that the word may ultimately come from a language of India or Sub-Saharan Africa. ${ }^{25}$ Most frequently Wanderwörter represent names of animals, culture plants, minerals, vessels etc. Quite often a Wanderwort is restricted to certain regions, in which case one may speak about an areal word.

\section{Alleged Anatolian borrowings in Greek: a critical review}

The evidence for alleged influence of Anatolian languages on early Greek is based on the following representative cases:

1) Possibly the most popular correspondence figuring almost in every discussion of Greek-Anatolian linguistic contact is one between Greek $\delta \dot{\tau} \pi \alpha \varsigma$ 'beaker, goblet', whose lin-

${ }^{25}$ For a recent and balanced discussion of the word see Hawkins 2013: 145-149. 
guistic predecessor is attested already in Linear B as di-pa, and Luwian tipas- (or, actually, tibas-, cf. below) 'sky'. ${ }^{26}$ This case is accepted as the most likely example of Anatolian lexical borrowing in Greek even by more cautious researchers, such as Melchert (2003: 184), Yakubovich (2010: 146) and Hajnal (2014: 110), and has triggered further speculations on Anatolian influence in the Greek mythological/literary tradition ${ }^{27}$. Despite certain phonetic similarity of the words, the case represents at a closer glance a clear example of a linguistic chimera. The fact that has triggered the idea is that Hieroglyphic Luwian sign L.182 dubbed as CAELUM ('sky') is used in the writing of both the word for 'bowl' and for 'sky', from which one made a tacit inference that Luwian had the same word for both notions; in support a Hittite vessel name tapiššana- was pointed out. ${ }^{28}$ Based on this, it was further supposed that the Greeks took over the word for 'bowl' (tipas-) from Luwians transforming it to depas. Both Anatolian and the Greek part of the equation are flawed by several misconceptions.

The first concerns HLuw. sign L.182 (CAELUM) and its function in spellings of the words for 'sky' and 'bowl'. As was already pointed out by Zs. Simon (2009: 248, fn. 5 and 2016) the attested form of the word for 'bowl' CAELUM.PI29 cannot conceal the same word as ("CAELUM")ti-pa-s- 'sky', for the obvious reason that the phonetic parts of the two words do not correspond, irrespectively whether one takes <pi $>$ in the spelling of the word for 'bowl' as phonetic complement (which renders the final part of the word) or phonetic indicator (which renders its initial part). However, contra Simon 2016, there is absolutely no necessity to assume another word for 'bowl' homonymous with the Luwian word for 'sky'. The sign CAELUM represents in all probability an ideogram referring to a hemispherical object, since perception of sky as a sort of hemisphere appears to be a universal found in many cultures. Consequently, the sign has nothing to do with the phonetics of the words it stands for and there is no reason to think that the usual Luwian word for 'bowl' corresponded to that for 'sky' in more than one labial consonant $p / b .{ }^{30}$

On the other hand, despite surface phonetic similarity of the Luwian word for 'sky' with Greek $\delta \varepsilon \dot{\varepsilon} \pi \alpha \varsigma$, there are a few problems with it. First, the initial stops in Anatolian were in all probability by default voiceless (an areal feature) and Melchert's (2003: 184) claim that some of them could be voiced if coming irregularly from older $n$ - is an ad hoc assumption put forward only to explain just the present case. ${ }^{31}$ A recent attempt of by Simon (2017: 258-260) to postu-

${ }^{26}$ The phonetic correspondence was noticed long ago (cf. review of the literature in Simon 2017(a): 248, fn. 8), but gained popularity mainly in the wake of the discussion by Neu (1999).

${ }^{27}$ Watkins 2007, cf. García-Ramón 2011: 88-89 and Teffeteller 2015: 721 with further literature.

28 See Laroche 1960: 96-97 with further refs.

${ }^{29}$ Three known attestations of the word CAELUM.PI (one on the KINIK bowl and two on the ANKARA silver bowl) has been supplemented recently by a fourth one on yet another bowl from the Ankara museum (ANKARA 3), see publication by Çıftçı-Hawkins (2016) and further discussions in Poetto 2017 and Simon 2017(b).

${ }^{30}$ Given the fact that the spelling CAELUM.PI is attested already on the KINIK bowl, dated before 1200 BC, the interpretation of $<\mathrm{pi}>$ as phonetic indicator hinting at the initial syllable of the word might seem preferable, as this would accord with the usual Empire Period practice, seen, e.g., in such spelling as VIR.ZA/I for zìdi- 'man', MONS+TU for PN Tudhaliya, LABARNA+LA for title labarna and, quite probably, DOMINUS.NA for nāni- 'leader, lord' (cf. Oreshko 2014, 620). Unfortunately, cuneiform texts seem to attest no vessel name beginning with pi- (cf. list of vessels with determinative DUG in Tischler 2008: 218-219) so the possibility remains hypothetic. If one takes $<$ pi $>$ as phonetic complement, the simplest possibility would be to read the word as huppi- (huppa-) which is attested in cuneiform (a vessel of unclear form), connecting it with the family of words for vessels including huppar(a)(from which hupp(a)rala- 'potter' is derived), hupparanni- 'bowl', huprušhi- 'incense-burner', hupurni- and hupuwaya-.

${ }^{31}$ Cf. considerations by Katz 2001: 219 and Yakubovich 2013: 119. A form with the initial voiced dental is of course quite likely for the initial phase of development from PA *nebos- (< PIE *nebhos-), but it is difficult to imag- 
late a new 'Luw(o)id language' which allegedly lacked initial devoicing of dentals does not seem in any way convincing. ${ }^{32}$ The character of the second stop is not without difficulties either: if in Kizzuwadna Luwian tappaš- clearly reflects the form with the stress on the first syllable effected by Čop's Law, the $i$-vocalization of the first syllable of HLuw. ti-pa-s- seems to point out that the stress in this form was on the second syllable and, consequently, the labial of PA * nebos- should have remained voiced/lenis. ${ }^{33}$ In other words, the most likely phonetic interpretation of HLuw. ti-pa-s- is /tibás-/ or /tebás-/ which is not quite the same as $\delta \varepsilon \dot{\tau} \tau \alpha \varsigma$.

Lastly, the Greek side of the correspondence is no less (if not more) problematic. The Homeric $\delta \varepsilon \dot{\tau} \tau \alpha \varsigma$ is not a 'bowl', but a 'beaker' or 'goblet', i.e. a much deeper vessel of a conical or bell-like shape, quite possibly on a stem, since stemmed drinking cups represented the most common type in the Aegean both in the $2^{\text {nd }}$ and in the early $1^{\text {st }}$ millennium BC (cf. kylix). Worse of that, the vessel referred in Linear B as di-pa was even further remote from whatever one might call a 'bowl'. Its form is known quite exactly from the ideograms ${ }^{*} 202^{\text {vas }}$ and * $241^{\text {VAS }+D I}$ which follow the phonetically spelled name of the vessel: it represents a sort of jar with or without handles which could be fixed at the upper rim. ${ }^{34}$ The early meaning of di-pa may still be glimpsed in several Homeric passages, most famously in the description of Nestor's $\delta \varepsilon \dot{\tau} \pi \alpha \varsigma$ in Il. 11.632-637 which implies that it was a large vessel provided with four handles. ${ }^{35}$ In sum, di-pa represents in all probability a word of Aegean substratum origin and has nothing to do either with the Luwian word for 'sky' (tibas-) or with that for 'bowl' whose reading is uncertain. ${ }^{36}$

ine that this distinction would have been preserved in the second part of the $2^{\text {nd }}$ millennium $B C$, since devoicing in the initial position as an areal feature should have affected any stop irrespectively of its origin.

32 The idea expands upon an earlier very tentative suggestion by Yakubovich (2013: 119) to identify the 'Arzawa Luwic' as a separate dialect/language put forward to explain just the initial voiced character of the dental in $\delta \varepsilon \dot{\tau} \alpha \varsigma$. All the other alleged Greek-Anatolian correspondences on the basis of which Simon elaborates the idea are extremely fragile, since, as in many other works, the sociolinguistic dimension of the phenomenon is simply disregarded and the crucial question why to borrow? is not asked at all. So, it is not clear why one should adduce Hitt.

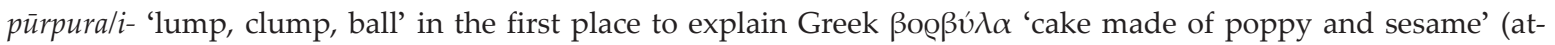

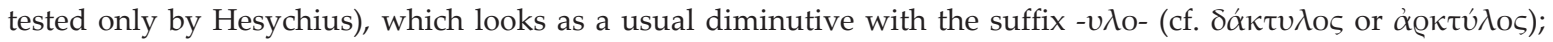
even if no underlying * ${ }^{*} \varrho \beta o \varsigma / \eta$ is attested, the morphology of the word alone speaks against a borrowing scenario, as does the not-too-impressive semantic correspondence (given the culinary associations of $\beta$ o@ $\beta$ v́ $\lambda \alpha$, a

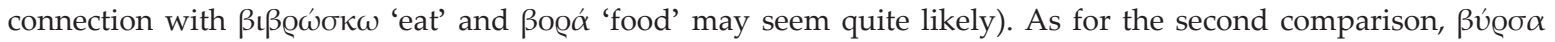
'skin stripped off, hide' vs. Hitt. kurša- 'skin, hide, fleece, (hunting) bag', it is quite impossible to reconcile the phonetic forms of the words using a borrowing scenario; again, it is not clear why 'skin' should be borrowed from Anatolia, since the Aegean was, without any doubt, pretty well supplied with locally produced skins and bags made thereof. No more clear is the need to borrow a name for 'small round net (used esp. for oystercatching)' ( $\gamma \alpha \dot{\gamma} \gamma \gamma \alpha \mu \mathrm{ov})$ from Anatolia (cf. Hitt. kānk- 'hang'): the Aegean fishermen were quite probably much more experienced in 'oyster-catching' - as well as in any other type of activities connected with the sea - than their Central Anatolian colleagues and were probably well aware that the process of collecting oysters does not actually involve any 'hanging'. Lastly, the toponym $\Delta \alpha \mathrm{tv} \iota$, an allegedly 'Luw(o)id' counterpart of Greek 'E $\lambda \alpha$ í $\alpha$ derived from Luwian tāin- 'oil', represents an egregious example of a linguistic chimera whose existence is due exclusively to the recent 'Luwian fashion' (the name is 'emended' from Kí $\alpha \iota \iota \iota \varsigma$, the actual name given by Stephen of Byzantium as an older name of 'E $\lambda \alpha$ í $\alpha$, cf. Starke 1998: 457 and 475 with further refs.).

${ }^{33}$ Cf. Kloekhorst 2008: s.v. nēpiš with further refs.

${ }^{34}$ For the ideogram see, e.g, Bernabé-Luján 2008: 224. The vessel di-pa and the respective ideograms figure, for instance, on the famous tablet PY TA 641 which features di-pa qe-to-ro-we, di-pa ti-ri-jo-we and di-pa a-no-we provided with ideograms featuring four-handled, three-handled and a jar without handles respectively.

${ }^{35}$ Cf. already Ventris-Chadwick 1973: 326-327 and 493.

${ }^{36}$ Only a brief mention deserves an idea going back to Furnée (see ref. in Puhvel 1997: s.v. kukupala-) and recently favored by Hajnal (2011: 111), that another Greek vessel name, кú $\varepsilon \varepsilon \lambda \lambda$ ov 'big-bellied drinking vessel, beaker, goblet' is somehow connected with Hittite DuGkukupal(l)a- or, apud Hajnal, with Hittite hupalla/i- 'skull'. 
2) Another correspondence which is favorably mentioned both by Yakubovich (2010: 147) and Hajnal (2014: 110) is кú $\mu \beta \alpha \lambda$ ov 'cymbal' vs. Hittite GIšhuhupal whose meaning is generally defined as 'a sort of percussion instrument', ${ }^{37}$ which is, however, by far not proven (cf. below). This connection is, however, not mentioned in either of Greek etymological dictionaries, and for a good reason: there are enough other possibilities to connect the Greek word, beginning with Greek $\kappa \dot{\mu} \mu \beta \eta$ 'drinking-cup, bowl; boat' (with associated $\kappa u ́ \mu \beta o \varsigma$ and $\kappa v \mu \beta i ́ o v)$, from which $\kappa u ́ \mu \beta \alpha \lambda$ ov is considered to be simply a diminutive; a connection with Skr. kumbhá- and Av. xumba- 'pot' and MIr. vessel names comm and cummal remains a possibility, although the underlying root for 'hollow thing' (as a bowl or ship) may equally be an Wanderwort. ${ }^{38}$ As for GIšhuhupal, or, more precisely, GIŠhuhubal, given the non-geminate spelling of the labial, it presents no clear advantages in comparison with traditional connections. First and foremost, the meaning of the word is not established with any certainty. ${ }^{39}$ The usual classification of Gišhuhubal with the percussion instruments is based on the fact that the instrument could be 'struck' (Hitt. walh- and hazzik(k)-), which would fit, however, not only for 'cymbals' but also for a 'tambourin' or a 'drum'. However, the verb as a technical term is in this case finally ambiguous and it is not excluded that we are dealing with a sort of string instrument with a specific technic of playing, comparable with a 'lute'. But even if one accepts identification of GIšhuhubal as a percussion instrument, the determinative of wood (GIŠ) regularly used with the word would favor rather meaning 'tambourin' or a 'drum'. The determinative speaks at the same time more or less strongly against interpretation of Gišh̆hhubal as 'cymbal', since manufacture of the latter from metal was essential for its characteristic shrill sound; a pair of 'cymbals' made of wood may function at best as a sort of castanets. ${ }^{40}$ Some distant connection of the Anatolian and Greek words is not excluded - as both 'tambourin' or 'drum' are finally 'hollow things' - but a borrowing scenario from Hittite into Greek appears to be highly unlikely.

3) In a way very similar (and even partly interrelated) case represents the alleged pair of correspondences Greek кú $\mu \beta \alpha \chi 0 \varsigma$ 'crown of a helmet' - found only once in Homer (Il. 15.536) as a substantive ${ }^{41}$, but also used adverbially 'head-foremost' - vs. Hitt. kupahi 'a headgear', which is known to be present also in Hurrian as kuwahi (cf. Yakobovich 2010: 147 and Hajnal 2014: 110). On the one hand, the word does not have a particularly foreign appearance, as

The first term is attested in only one text (see Puhvel loc.cit.) which gives absolutely no indication what sort of vessel it is; one may note, however, that non-geminate spelling of the labial points to $/ \mathrm{b} /$. A connection with Akkadian kukubu 'jar' is quite likely (either as an Akkadian borrowing or as an areal term). As for Hitt. hupalla/i- (or, again, rather huballa/i-, which may mean not 'skull' but 'scalp'(!), cf. Puhvel 1991(b): s.v. hupallas-), it cannot by definition be seriously considered as an immediate source of the Greek word, even if some distant genetic connection is not completely excluded, which goes also for several other words in Greek and other IE languages ( $\kappa u ́ \mu \beta \eta$ and $\kappa u ́ \pi \eta$,

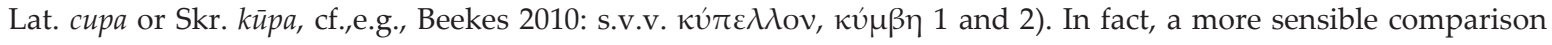

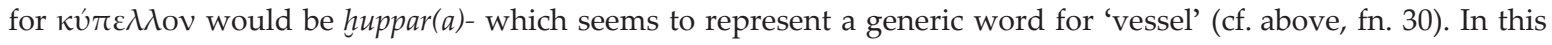
case, one would have to assume an example of an areal word rather than specific borrowing from Anatolian.

${ }_{37}$ See Puhvel 1991(b): s.v. huhupal-, basing apparently on earlier considerations of Furnée.

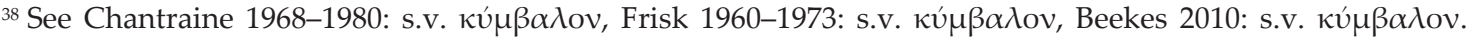
Cf. also Arm. *kumb- 'emboss of a shield', see Martirosyan 2009: s.v.

39 See detailed discussion in Schuol 2004: 108-112; for an earlier discussion cf. Dinçol 1998 with further refs.

${ }^{40}$ Moreover, there are good reasons to identify 'cymbals' in galgalturi- which is used just with determinative for 'copper' (URUDU), cf. discussion in Schuol 2004: 124-129.

${ }^{41}$ Note that Abbenes in Lexikon der Frühgriechischen Epos (LfgrE): s.v. $\kappa u ́ \mu \beta \alpha \chi o \varsigma$ interprets the substantive meaning of the word as secondary having originated from wrong analysis of a different collocation. This is quite dubious as morphologically кú $\mu \beta \alpha \chi 0 \varsigma$ does not look like an adverb and from the semantic point of view the expression has to be based on the word for "head"/"headgear". 
there are several parallel formations in - $\alpha \chi 0 \varsigma$ in Greek, such as oủ @í $\alpha \chi 0 \varsigma$ or $\sigma \tau$ tó $\mu \alpha \chi 0 \varsigma$, and furthermore it is hardly possible to separate $\kappa \hat{v} \mu \beta \alpha \chi 0 \varsigma$ from $\kappa v ́ \beta \eta / \kappa v ́ \mu \beta \eta$ 'head' and verb $\kappa \cup \beta \iota \sigma \tau \alpha ́ \omega$ 'tumble head-foremost'; a connection with $\kappa \hat{u} \mu \beta \eta$ 'drinking-cup, bowl' (and then with further IE words) is likely both typologically and in view of the doublet $\kappa u ́ \beta \eta / \kappa u ́ \mu \beta \eta .{ }^{42}$ On the other hand, interpretation of the word as a borrowing from Anatolian has no obvious advantages. As a matter of fact, $\kappa v ́ \mu \beta \alpha \chi 0 \varsigma$ is not a 'helmet' itself and the context of its sole attestation in Il. 15.536 does not make an impression that it is a special military terminus technicus taken over from a foreign tradition. It should be remembered that a borrowing scenario presupposes an exact or nearly exact correspondence in meaning. It is also noteworthy that the correspondence Anatolian $\mathrm{h} \sim$ Greek $\chi$ is not regular (one would expect $\kappa / \gamma$ in Greek), even if not impossible. As for kupahi/kuwahi, whose precise meaning is not quite clear, it may well be a Hurrian word, since it does indeed frequently appear in Hurrian texts and similar formations in -ahi are attested in Hurrian. ${ }^{43}$ A connection with Hebrew kōba'/qōba' 'helmet, turban' looks very attractive; a Philistine connection of the Hebrew word is possible, but far from proven. More probable still seems that the word has been taken over into Hebrew from Hurrian (directly or indirectly) at the time of the Hurrian supremacy in Syria around 1400 BC and, consequently, there is no specific Aegean connection of the word at all.

4) Quite different is the situation with the next correspondence, the one that is generally favored by Classicists but more soberly assessed by Anatolianists. All three Greek etymological dictionaries mention the Hittite word (NA4)ku(wa)nna(n)-, whose meaning is generally cited as 'copper; copper-ore (probably azurite); bead', as a likely source of kúavos 'dark-blue enamel, lapis-lazuli' (later also 'blue copper carbonate'), which is attested already in Linear B (ku-wa-no) presumably in the same meaning. ${ }^{44}$ It has, however, been pointed out that both words demonstrate certain phonetic similarity also with Akkadian $u q n \hat{u}$ which means 'lapis lazuli; lapis lazuli color', with which Ugaritic ign(i) $u$ is quite probably connected; if one accepts the connection, the word may be properly defined as Wanderwort 45 , which would most probably exclude it from the list of Anatolian borrowings, since there is no special reasons to connect either lapis-lazuli or dark-blue enamel with Anatolia. ${ }^{46}$ However, the case proves to be even more problematic if one looks deeper into the Hittite material. ${ }^{47}$ As a matter of fact, there is no contexts which speak for a meaning of (NA4) $k u(w a) n n a(n)$ - as 'copper-ore'; the only meanings which may be with reasonable certainty inferred from the contexts is that $k u(w a) n n a(n)$ means 'bead(s)' when (predominantly) used with determinative for 'stone' $\left(\mathrm{NA}_{4}\right)$, corresponding to Sumerographic NA4NUNUZ, and 'copper' when used without it. The meaning 'copperore' is only an assumption produced out of the wish to bridge the two divergent meanings of the word, namely 'copper' and 'bead', and, further, to connect it with Greek kúavos. ${ }^{48}$ However, $k u(w a) n n a(n)-$, as was pointed already by Puhvel, is definitively not lapis-lazuli, which is

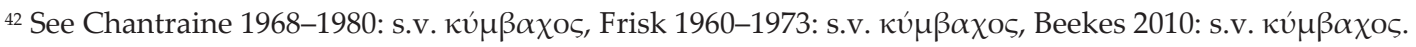

${ }^{43}$ See the detailed and balanced account of Puhvel 1997: s.v. kupahi-. Cf. also the short discussion and literature in Richter 2012: s.v. kub/wahi.

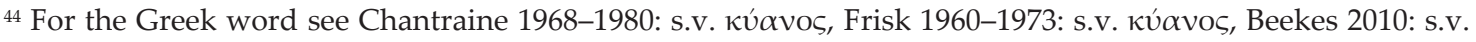

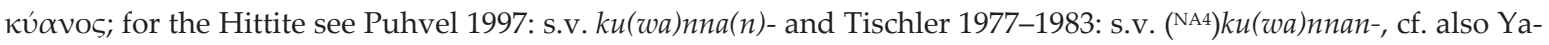
kubovich 2010: 147 with fn. 88, Giusfredi 2017.

${ }^{45}$ See Giusfredi 2017: 14 with further refs.

46 The source of lapis-lazuli for the whole Near East and the Aegean was in the $2^{\text {nd }}$ millennium BC in all probability Badakhshan in Afghanistan and the production of the blue enamel is connected first of all with Egypt.

${ }^{47}$ See attestations in Puhvel 1997: s.v. ku(wa)nna(n)-.

48 See Puhvel 1997: 310.
} 
spelled in Hittite texts NA4ZA.GÌN, since both are mentioned side by side (KUB 29.4 I 8-10) and, furthermore, seems to have no specific color connotations. Neither does it mean 'enamel' or 'glass', since the Hittite language used different terms for this sort of materials (Hitt. zapzagior Akkadian MEKKU and ANZAHHU).

The idea that $k u(w a) n n a(n)$ - designates a sort of mineral in Anatolian becomes even more dubious in view of the hitherto unrecognized Luwian piece of evidence, which is appropriate to address here briefly. Two texts of HLuw. corpus contain a title which may be read phonetically as kwan(n)anal(l)a-49. The context of both attestations in conjunction with a 'scribe' clearly suggests the meaning 'stone-mason, engraver'. ${ }^{50}$ Morphologically the word is quite transparent: it represents a derivative from $\operatorname{kwan}(n) a n(a)$ - with the Luwian suffix -alla/i- building names of professions. The root appears to be phonetically identical to that of $k u(w a) n n a(n)-$. As for semantic side, the connection becomes clear when one considers the pictographic form of the ideogram used with the title: sign $\mathrm{SA}_{4}$ (L.402) represents a circle with a further small circle inscribed in it. In view of the phonetic correspondence with $k u(w a) n n a n$ - there can be little doubt that the sign depicts a bead. Consequently, the original semantics of kwan(n)anal(l)a-should be 'bead-cutter' which was then generalized to 'stone-cutter'/'engraver'. The interpretation corroborates the impression created by cuneiform texts that NA4ku(wa)nna(n)- means only 'bead(s)'. If one dismisses the meaning 'copper ore' for the Anatolian word, its connection with kú $\alpha$ vos becomes rather illusive. There remains a slim possibility of a distant connection of the words if one proceeds from the assumption that the word was a Wanderwort with original meaning 'lapis-lazuli', which then took different meaning in different regions. However it is, the extant evidence gives no reason to see in the Greek word a borrowing specifically from any Anatolian language.

5) To the same semantical field as $k u(w a) n n a(n)$ - belongs a further word claimed to be an Anatolian borrowing. The Greek word for 'lead' whose standard literary form was $\mu$ ó $\lambda v \beta \delta$ os, but the older Mycenaean form was mo-ri-wo-do (/moliwdos/), was connected by Melchert (2008) with Lydian word mariwda-. The latter represents a deity name attested only once in the Lydian corpus (LW 4: 4); however, its appearance in association with god Sanda (Sãntas) suggests that the name may be identical to HLuw. Marwāy(a)-deities ((DEUS)mara/i-wa/i-i-zi-i (nom.pl.) in KULULU 2, §6) and further to CLuw. DMarwāy(a)- and Hitt. DMark(u)waya-, whose name is connected with PIE stem *mergw- and, accordingly, interpreted as the 'Dark ones'. The suggestion looks prima facie very attractive, since it presents a sensible explanation for the inner semantics of $\mu$ ó $\lambda u \beta \delta o s$ ('dark metal') and the idea to look for the source of the Greek word in Anatolia, which is considered to be a region with very old and rich metallurgical tradition, looks entirely sound. ${ }^{51}$ That said, one should point out that almost every element of the hypothesis is fraught with uncertainty and that the resulting structure is extremely fragile. To begin with the Greek part, $\mu$ ó $\lambda v \beta \delta$ os represents only the standard and the most frequent

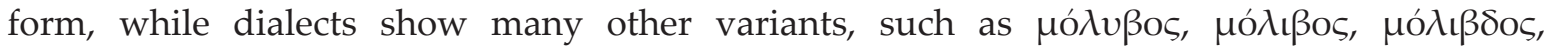

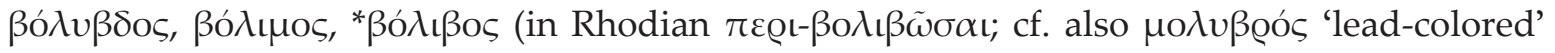
(Hesych)). ${ }^{52}$ Despite the fact that the Mycenaean mo-ri-wo-do is the oldest form, there are actually no special reasons to proclaim it 'more correct', since there are a priori no objective criteria

${ }^{49}$ BOYBEYPINARI 1 §11: SA 4 -na-na-la- and IVRIZZ fr. 2: ('SA $\left.{ }_{4}\right) k w a / i-n a-n a[-l a]-$, for the texts see Hawkins 2000: 530 and 336.

${ }^{50}$ Cf. also discussion in Payne 2010: 183.

${ }^{51}$ Besides Hajnal 2014: 111, the etymology is favored by Beekes (2010: s.v. $\mu$ ó $\left.\lambda v \beta \delta o s\right)$.

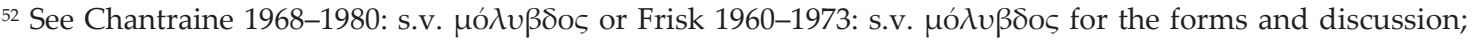
cf. further Beekes 2010: s.v. $\mu$ ó $\lambda v \beta \delta$ os. 
of this 'correctness'. ${ }^{53}$ The variation clearly shows that the word is originally non-Greek. In view of this variability, the connection with Latin plumbum, Bask berún or German Blei (OHG blīo/blizwes), suggested earlier, does not seem too outlandish (cf. also the variation $\mu / \beta$ in Greek itself, seen, e.g., in $\beta \lambda \tilde{\omega} \sigma \kappa \omega$ vs. $\mu$ o $\lambda \varepsilon \tilde{\imath} v)$. On the other hand, one should clearly realize that we do not have Lydian word for 'lead'; the only known Anatolian word for the metal is Hitt. šuläi. As for the Lydian Mariwda-, there is every reason to see in it a Luwic borrowing. The scarce evidence which we have on the reflection of PIE $g^{w}$ in Lydian suggests that it developed either to simple tectal $k$ (as in kãna 'wife' < PIE * $\left.g^{w} e n-e h 2\right)$ or to voiceless labiovelar $k^{w}$ (-qãn- 'strike/hit' < PIE * $g^{w} e n$ - 'strike'), as admitted earlier by Melchert (1994: 357). Consequently, PIE *merg ${ }^{w}$ - should have reflected in Lydian as *marq- (or, less likely, *mark-). $\operatorname{Marw} \bar{a}(y) a-$ on the other hand represents a specifically Luwic form reflecting the development $g^{w}>w$. Thus, Lydian cannot be the source of Greek $\mu$ ó $\lambda v \beta \delta o s ;$ nor is it likely to see it in Luwian, as marwa- proves to be rather far phonetically from any of the forms attested in Greek. As a result, the Anatolian origin of the word proves to be quite unfounded.

6) The third comparable case of a word for a material allegedly coming from Anatolia is Greek $\dot{\varepsilon} \lambda \dot{\varepsilon} \phi \alpha \varsigma$ 'ivory', which is attested already in the Mycenaean Greek (e-re-pa). Although less frequently than in the two previous cases, one still sporadically finds a claim that the word is a borrowing from Hittite (or Luwian) lahpa-/lahba- (e.g., Hawkins 2013: 225) 54, or, at least, that it has come into Mycenaean through Hittite/Anatolian mediation (Gasbarra-Pozza 2013), which is based (in part) on the now obsolete idea that Anatolia was an important ivory production center (cf. Masson 1967: 80-83 or Chantraine 1968-1980: s.v.). An Anatolian source of $\dot{\varepsilon} \lambda \dot{\varepsilon} \phi \alpha \varsigma$ is, however, hardly credible. On the one hand, Anatolia is not and has never been a natural habitat of modern species of elephants. There were only two regions adjacent to the Mediterranean in which elephants could be found in the Late Bronze Age: Africa (primarily Sub-Saharan) and the valley of the Orontes in Syria (for the latter see Çakırlar-Ikram 2016 and Pfälzner 2016). It is quite obvious that the words for 'ivory, elephant' found in the languages of the Mediterranean, if indeed borrowed, should come from either of these two regions. On the other hand, there is nothing in the phonetics of the Greek word which would in any way require the assumption of an Anatolian intermediary stage. On the contrary, assuming an Anatolian source, one would expect something like ${ }^{*} \lambda \alpha \gamma \beta \alpha \varsigma /{ }^{*} \lambda \alpha \kappa \tau \alpha \varsigma$ in Greek. Thus, under the assumption that $\dot{\varepsilon} \lambda \dot{\varepsilon} \phi \alpha \varsigma$ and lahpa-/lahba- are indeed foreign terms in Greek and Anatolian, one should conclude that both words are independent reflections of a term found in a third language. Taking into consideration the distribution of the elephant itself and that of the terms for it, the most obvious candidate would seem to be a language spoken in the Orontes valley - and not in Africa, as assumed in Beekes 2010: s.v. and indirectly implied in Frisk 1960-1973: s.v. The language of the Orontes valley in the Late Bronze Age could only be a dialect of Northwest Semitic, close either to Ugaritic or to the language of the Amorites. The problem is, however, that the Semitic terms for 'ivory' and 'elephant' are well known and they demonstrate no similarity with the Greek and Anatolian terms: cf. Akkadian pîru 'elephant' and šin pîri 'elephant tooth > ivory' (corresponding to Sum. ZÚ.AM.SI), which also yielded Hurrian šinniberi 'ivory' (and šinniberohhe 'made of ivory'); both Akkadian and Ugaritic also used the simple word for 'tooth' for the material (šinnu and šn respectively). So far, no traces

${ }^{53}$ Inter alia the variants show that $-d$ - was not an indispensable part of the word (cf. earlier attempts to explain it as secondary development from *-y-, see literature in the previous $\mathrm{fn}$.). This in any case has bearing on the question of source, since the presence of $-d$ - was the reason why Melchert connected the word specifically with Lydian (and not with Luwian).

${ }^{54}$ For attestations and discussion of the Hittite word s. Puhvel 2001. 
of anything reminiscent of $\dot{\varepsilon} \lambda \dot{\varepsilon} \phi \alpha \varsigma$ or lahpa-/lahba- have been attested in association with ivory in the Semitic tradition ${ }^{55}$. Given this fact, an assumption that both in Hittite and Greek the term represents an inherited term of Indo-European origin becomes practically inevitable. Taking into consideration the Near Eastern terms, one may tentatively suggest that $\dot{\varepsilon} \lambda \dot{\varepsilon} \phi \alpha \varsigma$ or lahpa-/lahba- reflects an old Indo-European term for 'tusk' or 'bone' or the like. ${ }^{56}$

7) One more example of an Anatolian lexical borrowing in Greek cited by Hajnal 2014: 111

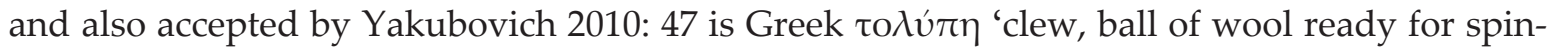
ning or of spun yarn; globular cake' vs. Hitt./Luw. taluppi- 'lump, clod (of earth or dough)' and tarupp- 'assemble, collect', which goes back to Melchert (1998) elaborating upon an earlier suggestion of Joseph (1982). ${ }^{57}$ The phonetic correspondence is rather exact and the somewhat divergent meanings of Greek and Anatolian words can be reconciled with some effort. However, there are strong doubts that a word of such semantics - especially when viewed against the rest of the evidence - can be borrowed at all. As noted above, a crucial prerequisite for a borrowing from a foreign language in a situation of casual language contact, is that the respective word is absent in the receiving language. This can hardly be the case with word for 'clew', since it is hardly possible to imagine that it was absent in Greek before the contact with the Anatolians. Such a basic thing is known in any culture which deals with wool of sheep (or other domestic animals), and should have been known both in the Aegean before the arrival of the Indo-European speakers and to the ancestors of the Greeks themselves for several millennia before their appearance in the Aegean. ${ }^{58}$ Another factor speaking against the borrowing scenario is that, on a closer consideration, there is a significant semantic distinction between

${ }_{55}$ An attempt by West (1992) to rehabilitate an old idea that غ̇ $\lambda \dot{\varepsilon} \phi \alpha \varsigma$ comes from Semitic 'lp 'ox, bull' is unconvincing. As has already been pointed out by Masson (1967: 82), the word for 'ox' is never used for 'elephant' and has no associations with 'ivory' whatsoever. It would be quite weird if the Greeks would adopt a Semitic name for 'ox' when the terms both for 'elephant' and for 'ivory' were readily available.

${ }^{56}$ The easiest way to reconcile the Greek and the Anatolian forms as inherited terms would be to assume a laryngeal metathesis in Anatolian lahpa- <*hlapa-, reconstructing the PIE root as * $h_{2} l e b^{h_{-}}$(and assuming an irregular synharmonic? - change in Greek: *alébha- $\left.{ }^{*}{ }^{*} e^{2} b^{h} a-\right)$. Curiously, a word with a comparable phonetic shape is indeed attested in Luwian: it is a word hidden behind the logogram L.85, conventionally transcribed as HALPA or GENUFLECTERE, which is used in the writing of the name of the Syrian city Haleb/Aleppo giving a phonetic clue for the reading of the ideographic TONITRUS.URBS 'City of the Storm-God' (cf. Hawkins in Herbordt 2005: 253). The sign depicts something like a human leg ('kneeling leg' in the definition by Hawkins, for the forms cf. Laroche 1960: 51) giving reasons for an assumption that Luwian had a term for leg or its part which sounded like *halpa- or *hlapa-. This is reminiscent of the picture with the German term for ivory Elfenbein < OHG helfant-bein, which is a

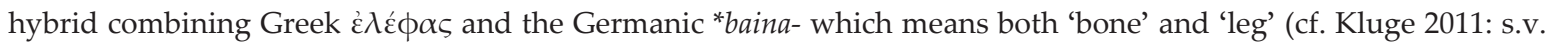
Elfenbein and Kroonen 2013: s.v. *baina-). One may tentatively suggest that in Luwian *hlapa- also meant both one of the long bones of the leg (shin bone or thigh bone) and could metaphorically be used for 'ivory'. It is also note-

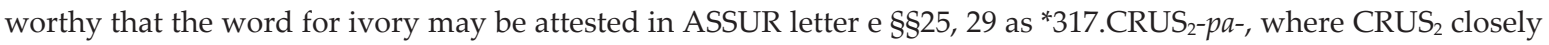
corresponds in shape to HALPA (the general trade context agrees with this interpretation, but is not specific enough to prove it). On the other hand, an old suggestion of Saussure to connect $\dot{\varepsilon} \lambda \varepsilon \dot{\phi} \phi \alpha \varsigma$ with PIE root for 'white' seen, e.g., in Lat. albus (s. Masson 1967: 81 fn. 7 for refs.) does not seem improbable. The root for 'white' may now be reconstructed as ${ }^{*} h_{2} e l b^{h_{-}}$(cf. de Vaan 2008: s.v. albus) and thus is extremely close phonetically to ${ }^{*} h_{2} l e b^{h}$. However, it is usually supposed that the root is reflected in Greek $\alpha \dot{\alpha} \lambda \phi \mathrm{s}$ 'barley groats', $\alpha \lambda \phi \phi o ́ s$ 'leprosy' and the river

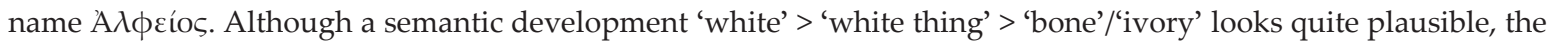
formal explanation of the connection between the two roots remains elusive (could one think about an unsteady nature of the laryngeal in the root, oscillating between $h_{1}$ and $h_{2}$ ?).

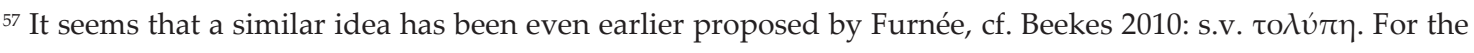
Hittite word see also Tischler 1991: s.v. taluppi-.

${ }^{58}$ Cf., e.g., Barber 1991. 
the Hittite and Greek words. As for Hittite, there are strong doubts that taluppi- had anything to do with 'wool', since the latter material, ubiquitously attested in different forms in the Hittite cultic texts, ${ }^{59}$ never appears in combination with taluppi-. In Greek, on the other hand,

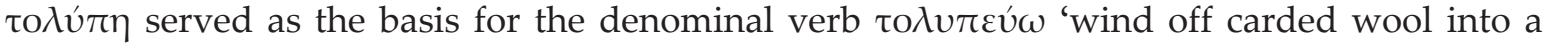
clew for spinning', which was used in the metaphorical sense 'achieve, accomplish', attested already in Homer (Il. 1.238, 4.490; Od.19.137). The evidence of this verb is important in two re-

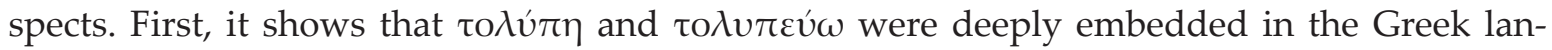
guage already in the relatively early period, which would hardly agree with its status of a recent borrowing. Second, the semantics of the verb shows that $\tau$ o $\lambda u ́ \pi \eta$ is first of all 'wound/prepared wool' which is essentially different from a simple 'clump of wool'. Thus, the borrowing scenario rather poorly agrees with the evidence. If we are not dealing with just a chance similarity, a more likely explanation for the case of $\tau 0 \lambda \dot{\tau} \pi \eta$ and taluppi- would then be an assumption that the words represent independent reflexes of a PIE stem with the general meaning 'assemble, collect' or the like, which would well account for differences in meaning. ${ }^{60}$

8) All the three Greek etymological dictionaries make a mention of a possible correspondence between Greek $\theta$ v́@oos, defined as a 'cultic wand' associated with the cult of Dionysos and HLuw. tuwarsa/i- 'vineyard' (with Beekes 2010: s.v. explicitly defining it as an Anatolian loan-word). ${ }^{61}$ However, Yakubovich (2010: 147), pointing out the irregular correspondence of initial dentals, suggested that both may be borrowings from a third source. This may be the case, but it is even more likely that the two words are not related at all.

Contrary to common assumptions, a connection of $\theta$ v́oбos with 'vine' is all but nonexistent. As a matter of fact, $\theta$ v́øoos is a 'rod' or 'staff' with which one can 'strike' and as such

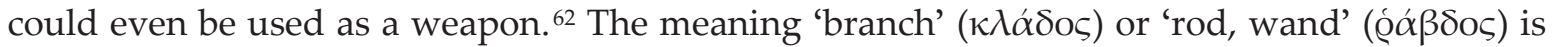

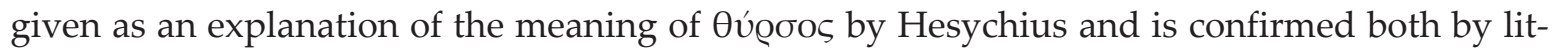

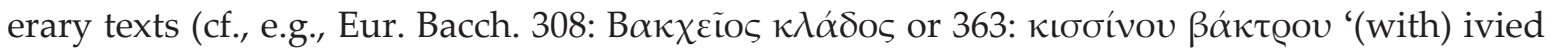
staff') and by the evidence of the vase painting where $\theta$ ó $\sigma 0 \varsigma$ as a usual attribute of the Maenads is depicted usually with a pine-cone at the end and wreathed in ivy (or, much less often, in vine-leaves). ${ }^{63} \mathrm{~A}$ very similar attribute of the Bacchic cult was vó $@ \theta \eta \xi$ 'giant fennel (Ferula communis)', and sometimes one gets the impression that it is simply another term for Өv́@oos (cf., e.g. Eur. Bacch. 147 or 1156). In fact, a scholiast even claimed that $\theta$

${ }^{59}$ Besides two forms of the word for 'wool', hüliya- and huülana-, frequently rendered simply by sumerogram SÍG (with or without a further logogram for color), one may mention the following Hittite terms: síghuttulli- 'strand (of wool)' < huett(i)-/huttiya- 'to draw, pull, pluck'; malkeššar 'spun wool' (?) < mālk- 'spin'; síGkiš(ša)ri- 'skein of carded wool(?)'; (SÍG)maišta- 'fiber, flock or strand of wool'(?); síGehurati- 'plug of wool'. Cf. further síGeššari-/ešri'fleece'; síGaštula-; kunza/i-; zum(m)inali- (a sort of wool). In Luwian is attested šūrit- 'skein of wool'.

${ }^{60}$ Melchert's proposal (1998: 50) to separate a prefix ta- (<PIE *to-) in the word does not seem convincing to me in view of paucity of parallel formations in Hittite. More plausible looks Kloekhorst's (2008: s.v. tarupp-) reconstruction of the root as *Treup- with development of a secondary epenthetic vowel after the dental. However, the position of the liquid may be different, and a reconstruction of the root as *Torp- with secondary development of epenthetic $u$ before labial is also thinkable. Whatever the situation might be, there are good grounds to add here some Slavic evidence: *tılpa-/*tılpa- 'crowd' (cf. OCS mıьna, Russ. moлna, Czech tlupa etc.) and Russ./Ukr. moлnezal mовпига 'fat and clumsy person' (see Vasmer 1950-1958: s.v. moлna; the Baltic connection discussed by Vasmer does not seem quite convincing).

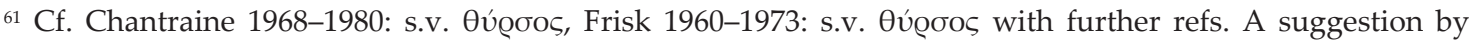

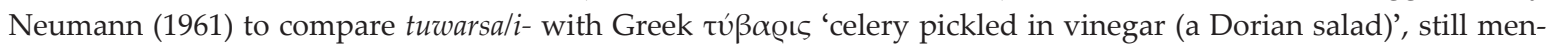
tioned by Hawkins 2010: 225, can hardly be taken seriously.

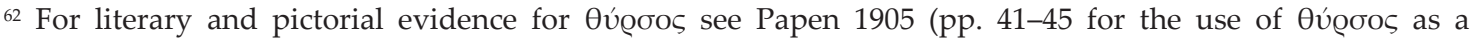
weapon).

${ }^{63}$ For pictorial evidence see Heinemann 2016: esp. 161-204. 


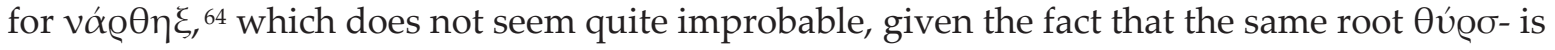

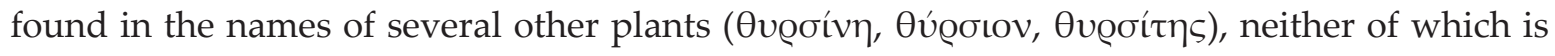
in any way connected with 'vine'. In sum, $\theta$ ó $\sigma o \varsigma$ is in no way a 'vine-branch', as many seem to tacitly assume, but is a sort of 'staff' functioning as an attribute of the orgiastic cult of Bacchus. Similarly, the latter deity is originally not a 'god of wine', but a god of ecstasy and cultic frenzy associated first of all with wild mountainous landscape and dancing. ${ }^{65}$ The word may well be non-Greek in origin and may be connected, as many aspects of the Dionysian cult seem to be, with Thrace.

As for the Luwian word, it is attested in Luwian texts only in the $1^{\text {st }}$ millennium BC. The usual Anatolian (both Hittite and Luwian) word for 'wine/vine', wiyana-, written mostly logographically as (GIŠ)GEŠTIN, designated quite probably also 'vineyard' (GIŠKIRI 6 .GEŠTIN). It is also noteworthy that all the certain attestations of the word tuwarsa/i- (spelled as tu-wa/i+ra/isà- with or without ideogram VITIS) are confined to two inscriptions found in Central Anatolia (BOR §3-4 and SULTANHAN §2, 22, 34, 36) ${ }^{66}$. In contrast, in KÖRKÜN §11 (South Eastern Anatolia) wi(ya)na/a- almost certainly means 'vineyard' and not 'vine'. If not due to the chance of attestation, the picture might suggest that tuwarsa/i- is (predominantly) a Central Anatolian term. Both this observation and the chronology of the attestations suggest that the word may be connected with appearance (or, possibly, rather spread) in Anatolia of peoples of Balkan origin, Phrygians and their relatives. ${ }^{67}$ Even so, it seems quite impossible to establish any semantic connection, even an indirect one, between tuwarsa/i- and $\theta$ v́ooos due to entirely discrepant meanings. Instead, a connection with Armenian torr 'vine, vine branch' suggested by Simon (2013: 116-117) looks not improbable. However, contra Simon, the evidence suggests rather that torr may be a genuine Armenian word brought from the Balkan homeland and tuwarsali-, accordingly, may be a Proto-Armenian borrowing in the late Central-Anatolian dialects of Luwian.

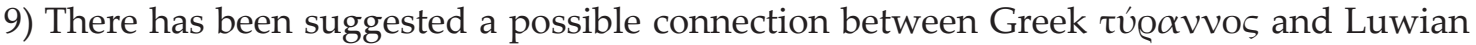
word usually read as tarwani- and interpreted as 'a sort of ruler' (with possible development from 'judge'). ${ }^{68}$ If one proceeds from this interpretation of the Luwian word, the fairly good phonetic correspondence makes a connection of the words very attractive, a possibility supported by the fact that specific professional titles are indeed often borrowed from language to language. The question would be rather if it is an Anatolian borrowing or an areal word of unclear origin, which is suggested by further possible cognates in Hebrew srn (applied to Philistine leaders) and Ugaritic srn. However, recent analysis by Melchert (forthcoming) essentially changes the perspective. Elaborating upon earlier considerations of Pintore, Melchert convincingly argued that the word, whose likelier reading is probably tarrawani-, is not a professional designation nor a title, but an adjective with the basic meaning 'just, righteous', which might be applied to a 'king' as well as to a 'servant' or even a 'wife'. This analysis makes it clear that the word is genuinely Luwian; on the other hand, the meaning of the word now proves to be

\footnotetext{
${ }^{64}$ See Papen 1905: 12.

${ }^{65}$ See, e.g., Schlesier 2011 with further refs. The original meaning and etymology of the term $\theta$ v́go addressed in greater detail elsewhere.

${ }^{66}$ Besides that, there is an ambiguous attestation in MARAŞ 8, $\S 6$ of the word spelled as (VITIS) $t u-w a / i-r i+i-t a$, which may be phonetically interpreted as $/ \mathrm{t}(\mathrm{u})$ warit(t)a/. It is doubtful that the word is to be simply amended to (VITIS)tu-wa/i-ri+i-sà!, but it may still be cognate with tuwarsa/i- (cf. discussion in Hawkins 2000: 254).

${ }^{67}$ For the argument that peoples culturally and possibly linguistically related with the Balkans were present in Anatolia already in the $2^{\text {nd }}$ millennium BC, see Oreshko 2017.

${ }^{68}$ The suggestion goes back to F. Pintore (1979). For a detailed analysis and a survey of earlier literature, see Melchert forthcoming.
} 
rather distinct from that of $\tau \dot{\varrho} \propto \alpha v v o \varsigma$ or, as far as one can judge, srn. It is not impossible that a usual collocation 'righteous ruler' would lead to perception of tarrawani- as a title on its own which might be borrowed into Greek and might be subsequently developed - with a sort of ironical twist - to 'absolute/unjust ruler'. However, it is perhaps telling that in Luwian itself the word did not develop into a stand-alone title and remained an adjective with broad meaning. It would also be justified to ask the question why the Greeks had to borrow tarrawani-, a word with quite an ambiguous reference to 'ruler', ignoring a much more straightforward and widespread word, which was used in slightly different forms as the usual designation for 'king', as far as one can see, in all parts of the 'Luwic world', e.g. in HLuw. handawati-, Lycian $x \tilde{n}$ tawat(i)-, Carian $k \delta o u-$ and possibly reflected also in Lydian PN Kandaules (as a borrowing from Carian)? In fact, accepting the interpretation of tarrawani- as 'righteous, just' and taking the evidence unbiasedly, one should conclude that the word has nothing to do with túgavvos (which still might be a loanword in Greek). ${ }^{69}$

10) One more example favorably assessed by Yakubovich (2010: 147) is Hitt. ešhar vs. Greek ¿ $\chi \omega \varrho$ 'blood of the gods; serum (later)', which goes back to a suggestion of Sayce (1922). However, neither of the Greek etymological dictionaries gives preference to this connection over other etymological suggestions, and with good reasons. There is an apparent phonetic discrepancy between the words: ešhar contains an additional sibilant which cannot just disappear in Greek; an expected outcome of the Hittite word in Greek would be * and the cluster -sk- is very stable in Greek. Moreover, one should note that besides Homer the word is rather well attested in later medical and natural philosophical literature referring to the 'watery part of animal juices'. It is rather difficult to imagine how an allegedly poetic word taken over from a foreign tradition to refer in a sort of elevated style to 'blood' could so quickly lose all its 'poeticness' and assume such a technical meaning. A more likely explanation is that the word is genuinely Greek and originally referred to some 'fluid of the body'; as a relatively vague term, it has been elevated by the Homeric tradition to a status of a poetic word, while in the everyday usage it kept its original meaning and was used by later scholars as a term.

11) Lastly, a mention should be made of my own (Oreshko 2013 (2015): 104-105) tentative suggestion concerning the bird name $\kappa u ́ \mu \iota v \delta\llcorner$ mentioned in Il. 14.291 as the name used 'in the language of men' for the bird known 'in the language of gods' as $\chi \alpha \dot{\alpha} \kappa \iota \varsigma$ which represents in

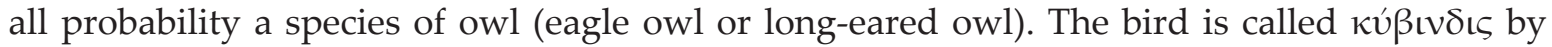
Aristotle, which seems to be quite close to the Anatolian word for 'copper', already discussed above $(k u(w a) n n a(n)-)$, suggesting that $\kappa u ́ \beta \iota v \delta ı \varsigma / \kappa u ́ \mu ı v \delta ı \varsigma$ might be a loan-translation of $\chi \alpha ́ \lambda \kappa \iota \varsigma$ (or vice versa). However, in view of the evidence presented above one may doubt that the Greeks knew any Anatolian language so well as to be able to 'translate' a bird name. Moreover, an alternative and simpler explanation is available. Like the designation for another species of owl $\kappa v \kappa v \mu(\omega) i \varsigma$, adduced for comparison earlier, the word could have an onomatopoetic origin, imitating the characteristic call of many owls (' $k u$ '). This possibility is supported by evidence from other IE languages: in Celtic the word for 'owl' is reconstructed as *kawanno-, but has in several languages $u$-vocalization of the first syllable (Middle Welsh cuan or Old Breton $\operatorname{cou}(h) a n)^{70}$, thus corresponding quite close to Greek $\kappa v ́ \beta เ v \delta ı \varsigma / \kappa u ́ \mu เ v \delta ı \varsigma$. Moreover, the initial part of the word corresponds to that of OHG huwo $\left(<{ }^{*} k u w o\right)$ and furthermore close to

${ }^{69}$ It is noteworthy that the phonetic side of the correspondence tarrawani- vs. $\tau u ́ g \alpha v v o \varsigma$ is also far from ideal, especially as far as vocalism is concerned. Proceeding from a borrowing, scenario the form which one would expect is something like ${ }^{*} \tau \alpha \varrho(\varrho) \alpha v(\mathrm{l}) \mathrm{o} \varsigma$ or ${ }^{*} \tau \alpha \varrho(\varrho)(\mathrm{o}) v v(\mathrm{l}) \mathrm{os}$.

${ }^{70}$ Matasović 2009: s.v. *kawanno-. 
that of Fr. chouette and Slavic word for the bird sova, which might well go back to something like *kou $\bar{a} .{ }^{71}$ It is thus very likely that $\kappa \hat{\prime} \beta \iota v \delta \iota \varsigma / \kappa u ́ \mu \iota \nu \delta \iota \varsigma$ is simply an $n d$-suffix extension of the same onomatopoetic root and $\chi \alpha \dot{\alpha} \lambda \kappa \iota \varsigma$ is a more descriptive term referring to the 'coppery' appearance of the bird.

\section{Conclusions}

Before proceeding to the actual conclusions, it seems useful to take a glance at the Lydian borrowings in Greek, which represent, as noted above, the clearest (if not the only) case of an Anatolian influence on Greek, in order to realize once again what 'normal' loanwords should look like. There are three clear cases of Lydian words in Greek texts ${ }^{72}$. The first one is $\pi \dot{\alpha} \lambda \mu \nu \varsigma$ 'king', a word known already to Homer as a personal name (of a Phrygian or Mysian leader), but used in its proper meaning by Hipponax of Ephesos in the $6^{\text {th }}$ century BC (frs. 1, 7.4 and 47.1), once by Aeschylus (fr. 437) and by several later authors ${ }^{73}$. The word represents an adoption of Lydian qa $m \lambda u$ - 'king' well attested in Lydian texts and seems to be a true borrowing comprehensible to a general Greek speaker, albeit with somewhat restricted usage, still apparently bearing a perceptible 'Oriental flavor', and thus comparable with English sultan or raja. ${ }^{74}$ The second word is $\kappa \alpha u ́ \eta \varsigma$, corresponding to Lydian kawe- 'priest/priestess'; the word is used by Hipponax (fr. 3.1) and later attested epigraphically. ${ }^{75}$ The word seems to be well known at least to the speakers of the eastern Ionian dialect. The third is $\beta \alpha \dot{\alpha \kappa \kappa \alpha \varrho ı \varsigma ~ w h i c h ~ r e f e r s ~ t o ~ s o m e ~}$ specific type of aromatic unguent and is used both by Archaic poets, such as Hipponax (fr. 107.21) and Semonides of Amorgos (fr. 14d), and by some $5^{\text {th }}$ century BC authors, such as Aristophanes (fr. 319), Aeschylus (fr. 14) or Ion of Chios (fr. trag. 24). ${ }^{76}$ The source language of the term is not completely clear, but the joint evidence of Hipponax, who associates the usage of

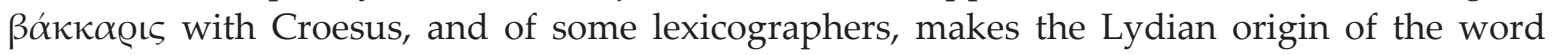
quite likely. The difference of these examples from those discussed above is obvious: the first two words almost exactly correspond to the Lydian counterparts phonetically and, more importantly, semantically, belonging to the category of professional designations/titles which are in general particularly frequently transferred from language to language. The third one is the name of a specific product and, as such, is very likely to be borrowed together with the product, as is the case with (eau de) cologne in English. The words clearly reflect cultural contacts between the Lydians and the Greeks, presumably mostly after ca. 700 BC, even if they still do not presuppose extensive bilingualism.

The results of this survey are certainly rather discouraging: considering the evidence soberly and without obsessive concentration exclusively on Anatolian and Greek, one should state that among the most frequently cited cases there is not a single one which may be properly qualified as contact-induced borrowing from an Anatolian language into Greek dating to the Late Bronze Age or Early Iron Age. Due to the limited scope of the study it is not possible

\footnotetext{
${ }^{71}$ Cf. Dersken 2008: s.v. *sovà.

72 The number of possible Lydian words in Greek may be larger (cf. Hawkins 2013: 155-194), but it is difficult to say about some other words attested in Hipponax and elsewhere whether they were known to common Greek speakers or had restricted usage.

${ }^{73}$ Cf. Hawkins 2013: 188-190.

${ }^{74}$ It is noteworthy that the form of the word in Greek with $\pi$ - corresponding to Lydian $k^{u}$ - suggests that it is a rather old borrowing, possibly dating back to the second millennium BC.

${ }^{75}$ Cf. Hawkins 2013: 183-187.

${ }^{76}$ Cf. Hawkins 2013: 156-157.
} 
to claim complete absence of any influence of the Anatolian linguistic milieu on Early Greek. However, in order to demonstrate it one would need to find more convincing examples meeting the usual criteria for loanwords. So far, there are only several cases in which some distant connection between the respective terms in Anatolian and Greek is not excluded, but it is not a borrowing strictu sensu. If there is something behind the similarity of the Greek and Anatolian words discussed above beyond accidental phonetic resemblance, it has to be explained not in the framework of a borrowing scenario, but in different terms, such as Wanderwort or areal features; the mechanisms of such a transfer is a separate and a complex question that cannot be addressed here.

In keeping with what has been said above about methodology, this conclusion has farreaching consequences for the question of Greek-Anatolian language interference in general. The virtual absence of direct lexical borrowings is a strong indication that there was no GreekAnatolian bilingualism and that even the level of casual contact was extremely low. This necessarily means that any influence on the other levels of language, such as phonology, morphology or phraseology, is impossible by definition, since morphology and phonetics come after words; but the words, as one can see, did not actually come from Anatolian into Greek. Similarly, the absence of bilingual communities makes it rather unlikely that the Greeks had any access to Anatolian literary texts (oral or written) and, consequently, an explanation for any eventual similarities in phraseology or literary themes between Greece and Anatolia - or, wider, the Ancient Near East - should be sought along different lines, such as generic or typological similarity, common heritage or common cultural experience.

\section{Literature}

Aikhenvald, Alexandra Y., R. M. W. Dixon, (eds.). 2001. Areal Difusion and Genetic Inheritance. Problems in Comparative Linguistics. Oxford / New York.

Bachvarova, Mary R. 2016. From Hittite to Homer. The Anatolian Background of Ancient Greek Epic. Cambridge.

Barber, E. J. W. 1991. Bronze Ages with special reference to the Aegean. Princeton University Press.

Beckman, Gary, Trevor Bryce, Eric Cline (eds.). 2011. The Ahhiyawa Texts (SBL 28). Atlanta.

Beekes, Robert S. 2010. Etymological Dictionary of Greek. Vols. 1-2. Leiden / Boston: Brill.

Beekes, Robert S. 2014. Pre-Greek. Phonology, Morphology, Lexicon. Ed. by Stefan Norbrius. Leiden: Brill.

Bernabé, Alberto, Eugenio R. Luján. 2008. Mycenaean Technology. In: Y. Duhoux, A. Morpurgo-Davies (eds.). A Companion to Linear B. Mycenaean Greek Texts and their World. Vol. 1 (Bibliothèque des Cahiers de l'Institut de Linguistique de Louvain 120): 201-233. Louvain-la-Neuve / Paris / Dudley.

Bianconi, Michele. 2015. Contatti greco-anatolici e sprachbund egeo-micrasiatico. Stato della ricerca e nuove prospettive. Archivio Glottologico Italiano 100(2): 129-178.

Brust, Manfred. 2005. Die indischen und iranischen Lehnwörter im Griechischen. Institut für Sprachen und Literaturen der Universität Innsbruck.

Burkert, Walter. 1992. The Orientalizing Revolution: Near Eastern Influence on Greek Culture in the Early Archaic Age. Trans. by M. E. Pinder and W. Burkert. Cambridge / London: Harvard University Press.

Burkert, Walter. 2004. Babylon, Memphis, Persepolis: Eastern Contexts of Greek Culture. Cambridge / London: Harvard University Press.

Cartledge, Paul. 1993. The Greeks: A Portrait of Self and Others. Oxford University Press.

Chadwick, John. 1988. The women of Pylos. In: J.-P. Olivier, T. G. Palaima (eds.). Texts. Tablets and Scribes: Studies Offered to Emmett L. Bennett, Jr. (Minos, Suppl., 10): 43-95. Ediciones Universidad de Salamanca.

Chantraine, Pierre. 1968-1980. Dictionnaire étymologique de la langue grecque: histoire des mots. Paris: Klincksieck.

Coleman, John E. 1997. Ancient Greek Ethnocentrism. In: John E. Coleman, C. A. Walz (eds.). Greeks and Barbarians: Essays on the Interactions between Greeks and non-Greeks in Antiquity and the Consequences for Eurocentrism: 175-220. Bethesda, MD: CDL Press. 
Çakırlar, Canan, Salima Ikram. 2016. 'When elephants battle, the grass suffers.' Power, ivory and the Syrian elephant. Levant 48(2): 167-183.

Çıftçı, Mine, John D. Hawkins. 2016. A New Inscribed Bowl in the Ankara Museum, Colloquium Anatolicum 15: 239-246.

Dardano, Paola. 2013. Lingua omerica e fraseologia anatolica: vecchie questioni e nuove prospettive. In: M. Mancini, L. Lorenzetti (eds.). Le lingue del Mediterraneo antico. Culture, mutamenti, contatti: 125-150. Firenze: Carocci.

Derksen, Rick. 2008. Etymological Dictionary of the Slavic Inherited Lexicon. Leiden / Boston: Brill.

Dinçol, Belkıs. 1998. Beobachtungen über die Bedeutung des hethitischen Musikinstruments Gišhuhupal. Anatolica 24: 1-50.

Fidio, Pia de. 2008. Mycenaean History. In: Y. Duhoux, A. Morpurgo-Davies (eds.). A Companion to Linear B. Mycenaean Greek Texts and their World. Vol. 1: 81-114. Louvain-la-Neuve /Paris / Dudley.

Frisk, Hjalmar. Griechisches etymologisches Wörterbuch. 1960-1973. Heidelberg: C. Winter.

García Ramón, José Luis. 2011a. Idiome in hethitischer Literatur und in griechischer Dichtung. Anatolische bzw. akkadische Lehnübersetzungen oder indogermanische Phraseologie? In: Manfred Hutter, Sylvia HutterBraunsar (eds.). Hethitische Literatur. Überlieferungsprozesse, Textstrukturen, Ausdrucksformen und Nachwirken. Akten des Symposiums vom 18. bis 20. Februar 2010 in Bonn: 83-97. Münster: Ugarit.

García Ramón, José Luis. 2011b. Sprachen in Kontakt im Griechenland und Kleinasien im 2. Jahrtausend v. Chr. In: Dietrich Boschung, Claudia Maria Rehl (eds.). Historische Mehrsprachigkeit. Workshop des Zentrums für Antike Kulturen des Mittelmeerraumes (ZaKMiRa) und des Zentrums Sprachenvielfalt und Mehrsprachigkeit (ZSM) an der Universität Köln, Juli 2008: 23-45. Aachen: Shaker.

Gasbarra, Valentina, Marianna Pozza. 2012. Fenomeni di interferenza greco-anatolica nel II millennio a.C.: l'ittito come mediatore tra mondo indoeuropeo e mondo non indoeuropeo. Annali dell'Istituto Orientale di Napoli N.S. 1: 165-214.

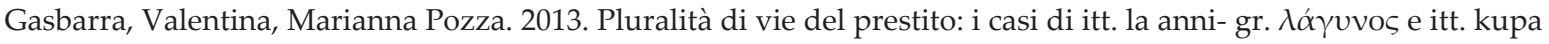
i-, gr. кú $\mu \beta \alpha \chi о \varsigma$. In: M. Mancini, L. Lorenzetti (eds.). Le lingue del Mediterraneo antico. Culture, mutamenti, contatti: 181-191. Roma.

Giannakis, Georgios K. (ed.). 2014. Encyclopedia of Ancient Greek Language and Linguistics. 3 Vols. Leiden: Brill.

Giusfredi, Federico. 2017. On Sumerian $\mathrm{ku}_{3}(\mathrm{~g})$-an (a metal) and some allegedly derived words. Nouvelles Assyriologiques Brèves et Utilitaires (N.A.B.U.) 2017(1): 13-16.

Gusmani, Roberto. 1964. Lydisches Wörterbuch. Heidelberg: C. Winter.

Haas, Otto. 1966. Die Phrygischen Sprachdenkmäler. Sofia: Académie bulgare des sciences.

Hajnal, Ivo. 2014. Die griechisch-anatolischen Sprachkontakte zur Bronzezeit - Sprachbund oder loser Sprachkontakt? Linguarum varietas 3: 105-116.

Hajnal, Ivo. 2018. Graeco-Anatolian contacts in the Mycenaean Period. In: M. A. Fritz, B. D. Joseph, J. S. Klein (eds.). Handbook of Comparative and Historical Indo-European Linguistics: 2037-2055. Berlin: De Gruyter.

Hall, Jonathan M. 2002. Hellenicity: Between Ethnicity and Culture. University of Chicago Press.

Haubold, Johannes. 2013. Greece and Mesopotamia: Dialogues in Literature. Cambridge University Press.

Hawkins, Shane. 2010. Greek and the Languages of Asia Minor to the Classical Period. In: E. J. Bakker (ed.): A Companion to the Ancient Greek Language: 213-227. Malden / Oxford / Chichester: Wiley -Blackwell.

Hawkins, Shane. 2013. Studies in the Language of Hipponax (Münich studies in historical linguistics, Bd. 14). Bremen: Hempen Verlag.

Heinemann, Alexander. 2016. Der Gott des Gelages. Dionysos, Satyrn und Mänaden auf attischem Trinkgeschirr des 5. Jahrhunderts v. Chr. Berlin / Boston: De Gruyter.

Herbordt, Suzanne. 2005. Die Prinzen- und Beamtensiegel der hethitischen Grossreichszeit auf Tonbullen aus dem Nişantepe-Archiv in Hattusa. Mit Kommentaren zu den Siegelinschriften und Hieroglyphen von J. David Hawkins (Boğazköy-Hattuša 19). Mainz: Verlag Philipp von Zabern.

Heubeck, Alfred. 1961. Praegraeca. Sprachliche Untersuchungen zum vorgriechisch-indogermanischen Substrat. Universitätsbund Erlangen.

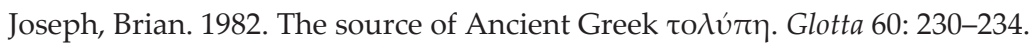

Katz, Joshua T. 2001. Hittite ta-pa-ka-li-ya-<aš>. In: O. Carruba, W. Meid (eds.). Anatolisch und Indogermanisch. Anatolico e indoeuropeo. Akten des Kolloquiums der Indogermanischen Gesellschaft, Pavia, 22.-25. September 1998: 205237. Institut für Sprachen und Literaturen der Universität Innsbruck. 
Kloekhorst, Alwin. 2008. Etymological Dictionary of the Hittite Inherited Lexicon. Leiden: Brill.

Kluge, Friedrich. 2011. Etymologisches Wörterbuch der deutschen Sprache. 25., durchgesehene und erweiterte Auflage, rev. von E. Seebold. Berlin: De Gruyter.

Kroonen, Guus. 2013. Etymological Dictionary of Proto-Germanic. Leiden / Boston: Brill.

Lamberterie, Charles de. 2013. Grec, phrygien, arménien: des anciens aux modernes. Journal des Savants 2013(1): 3-69.

Laroche, Emmanuel. 1960. Les hiéroglyphes hittites. 1: L'écriture. Paris: Éditions du Centre national de la recherche scientifique.

Laurot, Bernard. 1981. Idéaux Grecs et barbarie chez Hérodote. Ktema 6: 39-48.

Ligorio, Orsat, Alexander Lubotsky. 2013. Phrygian. In: Y. B. Koryakov, A. A. Kibrik (eds.). Languages of the World: Relict Indo-European, Languages of Western and Central Asia: 180-195. Moscow: Academia.

López-Ruiz, Carolina. 2010. When the Gods Were Born. Greek Cosmogonies and the Near East. Cambridge University Press.

Martirosyan, Hrach K. 2009. Etymological Dictionary of the Armenian Inherited Lexicon. Leiden: Brill.

Masson, Emilia. 1967. Recherches sur les plus anciens emprunts sémitiques en grec. Paris: Klincksieck.

Matasović, Ranko. 2009. Etymological Dictionary of Proto-Celtic. Leiden / Boston: Brill.

Mee, Cristopher. 1978. Aegean Trade and Settlement in Anatolia in the Second Millennium B.C. Anatolian Studies 28: 121-156.

Melchert, H. Craig. 1994. Anatolian historical phonology (Leiden Studies in Indo-European 3). Amsterdam / Atlanta: Rodopi.

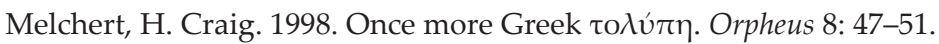

Melchert, H. Craig. 2008. Greek mólybdos as a loanword from Lydian. In: B. J. Collins, M. R. Bachvarova, I. C. Rutherford (eds.). Anatolian interfaces. Hittites, Greeks and their neighbours: 153-157. Oxford.

Melchert, H. Craig. Forthcoming. Iron Age Luvian tarrawann(i)-. Ms.

Metcalf, Cristopher. 2015. The Gods Rich in Praise. Early Greek and Mesopotamian Religious Poetry. Oxford University Press.

Mountjoy, Penelopa A. 1998. The East Aegean-West Anatolian Interface in the Late Bronze Age: Mycenaeans and the Kingdom of Ahhiyawa. Anatolian Studies 48: 33-67.

Mouton, Alice, Ian Rutherford. 2015. Arzawan Rituals and Greek Religion. In: N. Chr. Stampolidis, Ç. Maner, K. Kopanias (eds.). NOSTOI: Indigenous Culture, Migration and Integration in the Aegean Islands and Western Anatolia during the Late Bronze and Early Iron Ages: 709-736. Istanbul: Koç University Press.

Munson, Rosaria Vignolo. 2005. Black Doves Speak: Herodotus and the Languages of Barbarians (Hellenic Studies Series 9). Washington, DC: Center for Hellenic Studies.

Neu, Erich. 1999. Altanatolien und das mykenische Pylos: Einige Überlegungen zum Nestorbecher der Ilias. Archiv Orientální 67: 619-627.

Oreshko, Rostislav. The Strange Case of Dr. FRATER and Mr. DOMINUS: a Re-consideration of the Evidence Concerning Luwian nani-. In: P. Taracha, M. Kapełuś (eds.). Proceedings of the Eighth International Congress of Hittitology (Warsaw, 5-9 September 2011): 614-631. Warsaw: Wydawnictwo Agade.

Oreshko, Rostislav. 2013 (2015). Hipponax and the Linguistic, Ethnic and Religious Milieu of Western Anatolia. Some Further Notes on: Hawkins Sh. The language of Hipponax. Hephaistos 30: 88-112.

Oreshko, Rostislav. 2017. Hartapu and the Land of Maša. A New Look at the KIZILDAĞ-KARADAĞ Group. Altorientalische Forschungen 44(1): 1-21.

Oreshko, Rostislav. Forthcoming. Gods of the Lydians, Cultural Contact and the Problem of Lydian Ethnolinguistic Identity. In: Proceedings of the Conference 'In Search of the Golden Fleece'. Linguistic and Cultural Interactions between Greece and the Ancient Near East', Oxford, January 27-28, 2017.

Papen, Ferdinand Gaudenz von. 1905. Der Thyrsos in der griechischen und römischen Literatur und Kunst. Berlin: Reimer.

Payne, Annick. 2010. 'Writing' in Hieroglyphic Luwian. In: Itamar Singer (ed.). Ipamati kistamati pari tumatimis: Luwian and Hittite Studies presented to J. David Hawkins on the occasion of his 70th birthday: 182-187. Tel-Aviv University: Institute of Archaeology.

Pfälzner, Peter. 2016. The Elephants of the Orontes. In: D. Parayre (ed.). Le fleuve rebelle. Géographie historique du moyen Oronte d'Ebla à l'époque médiévale. Actes du colloque international tenu les 13 et 14 décembre 2012 à Nanterre (MaE) et à Paris (iNHa) (Syria, supplément IV): 159-182. Beyrouth: Presses de l'IFPO.

Pintore, Franco. 1979. Tarwanis. In: O. Carruba (ed.). Studia Mediterranea Piero Meriggi dicata: 473-494. Pavia: Aurora.

Poetto, Massimo. 2017. The Hieroglyphic Luwian Inscription ANKARA 3: A New Exegetic Approach. NABU 2017/2: 88-90. 
Pozza, Marianna, Valentina Gasbarra. 2014a. Multidirectional Lexical Borrowings in the Ancient Near East in the 2nd Millennium BC. Athens Journal of Philology 1(4): 245-258.

Pozza, Marianna, Valentina Gasbarra. 2014b. Some Sociolinguistic Reflections on the Aegean-Anatolian Interference in the 2nd Millennium BC. Athens: In: ATINER'S Conference Paper Series, 3-14. The Athens Institute for Education and Research.

Puhvel. Jaan. 1991a. Homer and Hittite. Institut für Sprachen und Literaturen der Universität Innsbruck.

Puhvel, Jaan. 1991b. Hittite Etymological Dictionary, Vol. 3: Words beginning with H. Berlin / New York: Mouton de Gruyter.

Puhvel, Jaan. 1997. Hittite Etymological Dictionary, Vol. 4: Words beginning with K. Berlin / New York: Mouton de Gruyter.

Puhvel, Jaan. 2001. Ivory and Elephant in Hittite. In: G. Wilhelm (ed.). Akten des IV. Internationalen Kongresses für Hethitologie, Würzburg, 4.-8. Oktober 1999: 561-562. Wiesbaden: Harrassowitz.

Puhvel, Jaan. 2002. Epilecta Indoeuropaea. Institut für Sprachen und Literaturen der Universität Innsbruck.

Richter, Thomas. 2012. Bibliographisches Glossar des Hurritischen. Wiesbaden: Harrassowitz.

Rosół, Rafał. 2013. Frühe semitische Lehnwörter im Griechischen. Frankfurt am Main: Verlag Peter Lang.

Rutherford, Ian. 2002. Some patterns in Lycian-Greek bilingualism. In: J. N. Adams, M. Janse, S. Swain (eds.). Bilingualism in ancient society: language contact and the written text: 197-219. Oxford University Press.

Rutherford, Ian. 2008. The Songs of the Zintuhis: Chorus and Ritual in Anatolia and Greece. In: B. J. Collins, M. Bachvarova, I. Rutherford (eds.). Anatolian Interfaces - Hittites, Greeks and Their Neighbours: 73-83. Oxford University Press.

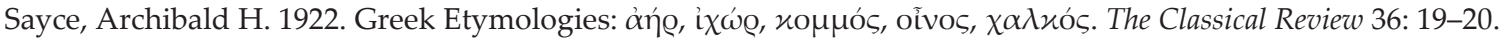

Schlesier, Renate. 2011. Der bakchische Gott. In: R. Schlesier (ed.). A Different God? Dionysos and Ancient Polytheism: 173-202. Berlin / Boston: De Gruyter.

Schmitt, Rüdiger. 1971. 'Méconnaissance' altiranischen Sprachgutes im Griechischen. Glotta 49: 95-110.

Schuol, Monika. 2004. Hethitische Kultmusik. Eine Untersuchung der Instrumental- und Vokalmusik anhand hethischer Ritualtexte und von archäologischen Zeugnissen. Rahden, Westfalien.

Simon, Zsolt. 2009. Die ANKARA-Silberschale und das Ende des hethitischen Reiches. Zeitschrift für Assyriologie und vorderasiatische Archäologie 99(2): 247-269.

Simon, Zsolt. 2013. Die These der hethitisch-luwischen Lehnwörter im Armenischen. International Journal of Diachronic Linguistics and Linguistic Reconstruction 10: 97-135.

Simon, Zsolt. 2016. Zum hieroglyphen-luwischen Zeichen CAELUM. NABU 2016(4): 159-162.

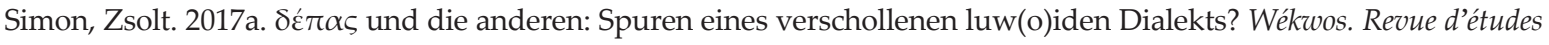
indoeuropéennes 3: 245-259.

Simon, Zsolt. 2017b. Philologische Bemerkungen zur hieroglyphen-luwischen Inschrift ANKARA 3. NABU 2017/2: 86-88.

Sowa, Wojciech. 2007. A note to Phrygian words in Greek. Studia Etymologica Cracoviensia 12: 153-170.

Sowa, Wojciech. 2008. Studien zum Phrygischen. Göttingen: E. Cuvilier.

Teffeteller, Annette. 2015. Songs by Land and Sea Descending: Anatolian and Aegean Poetic Traditions. In: N. Chr. Stampolidis, C. Maner, K. Kopanias (eds.). NOSTOI: Indigenous Culture, Migration and Integration in the Aegean Islands and Western Anatolia during the Late Bronze and Early Iron Ages: 709-736. Istanbul: Koç University Press.

Thomason, Sarah G. 2001. Language Contact: An Introduction. Edinburgh University Press.

Thomason, Sarah G., Terry Kaufman. 1988. Language Contact, Creolization, and Genetic Linguistics. Berkeley / Los Angeles / London: University of California Press.

Tischler, Johann. 1977-1983. Hethitisches Etymologisches Glossar. Teil I, A-K. Institut für Sprachen und Literaturen der Universität Innsbruck.

Tischler, Johann. 1991. Hethitisches Etymologisches Glossar. Teil III, Lieferung 8: T, D/1. Institut für Sprachen und Literaturen der Universität Innsbruck.

Tischler, Johann. 2008. Hethitisches Handwörterbuch - Mit dem Wortschatz der Nachbarsprachen, 2., vermehrte und verbesserte Auflage. Institut für Sprachen und Literaturen der Universität Innsbruck.

Tuplin, Christopher. 1999. Greek racism. Observations on the character and limits of Greek ethnic prejudice. In: G. Tsetskhladze (ed.). Ancient Greeks. West and East: 47-75. Leiden / Boston / Köln: Brill. 
Vaan, Michiel de. 2008. Etymological Dictionary of Latin and the Other Italic Languages. Leiden / Boston: Brill.

Vasmer, Max. 1953-1955. Russisches etymologisches Wörterbuch. Heidelberg: Carl Winter.

Ventris, Micheal, John Chadwick. 1973. Documents in Mycenaean Greek. Second Edition. Cambridge University Press.

Watkins, Calvert. 1995. How to Kill a Dragon: Aspects of Indo-European Poetics. Oxford University Press.

Watkins, Calvert. 1998. Homer and Hittite Revisited. In: P. Knox, C. Foss (eds.). Style and Tradition. Studies in Honor of Wendell Clausen: 201-216. Stuttgart / Leipzig: B. G. Teubner.

Watkins, Calvert. 2000a. L’Anatolie et la Grèce: Résonances culturelles, linguistiques et poétiques. Comptes Rendus des Séances de l'Académie des Inscriptions et Belles-Lettres 2000(144-3): 1143-1158.

Watkins, Calvert. 2000b. A Distant Anatolian Echo in Pindar: The Origin of the Aegis Again. Harvard Studies in Classical Philology 100: 1-14.

Watkins, Calvert. 2007. The Golden Bowl. Thoughts on the new Sappho and its Asianic Background. Classical Antiquity 26(2): 305-324.

West, Martin L. 1997. The East Face of Helicon. Oxford University Press.

West, Martin L. 1992. Elephant. Glotta 70 (3-4): 125-128.

Willi, Andreas. 2004. Old Persian in Athens Revisited (Ar. Ach. 100). Mnemosyne 57: 657-681.

Winford, Donald. 2013. Contact and Borrowing. In: R. Hickey (ed.). The Handbook of Language Contact: 170-187. Oxford / Chichester: Wiley-Blackwell.

Yakubovich, Ilya. 2010. Sociolinguistics of the Luvian Language. Leiden / Boston: Brill.

Yakubovich, Ilya. 2013. Anatolian Names in -wiya and the Structure of Empire Luwian Onomastics. In: A. Mouton, I. Rutherford, I. Yakubovich (eds.). Luwian Identities - Culture, Language and Religion Between Anatolia and the Aegean: 87-123. Leiden / Boston: Brill.

Yakubovich, Ilya. 2015. Phoenician and Luwian in Early Iron Age Cilicia. Anatolian Studies 65: $35-53$.

Ростислав Орешко. К вопросу об анатолийском влиянии на раннегреческий язык (1500800 гг. до н.э.): критика со стороны социолингвистики и ареального языкознания

В статье исследуется вопрос о возможном анатолийском влиянии на ранние стадии развития греческого языка (примерно с 1500 по 800 гг. до н.э.). Первая часть посвящена обсуждению общих методологических вопросов, связанных с языковыми контактами, таких, как механизмы языкового взаимодействия и масштабы заимствований. Во второй части критически обсуждаются 11 случаев потенциальных заимствований в греческий язык из анатолийских источников. Результаты анализа показывают, что анатолийское влияние на раннегреческий словарный состав было в лучшем случае минимальным, что, в свою очередь, фактически исключает возможность какого-либо влияния в области фонетики, морфологии и фразеологии.

Ключевые слова: греко-анатолийские контакты, раннегреческий язык, анатолийские языки, хеттский язык, лувийский язык, лидийский язык, ликийский язык, карийский язык. 